\title{
A REVIEW OF WATER RESOURCE POTENTIAL FOR DEVELOPING GEOTHERMAL RESOURCE SITES IN THE WESTERN UNITED STATES
}

\section{Hanford Engineering Development Laboratory J.C. Sonnichsen, Jr}

July 1980

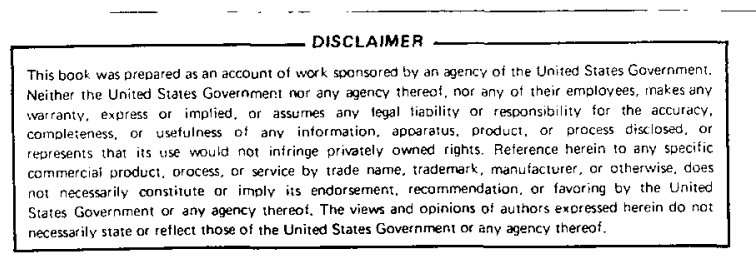

DISTREUTION OF THIS DOCUPAERT IS UALLIMITEB HANFORD ENGINEERING DEVELOPMENT LABORATORY Operated by Westinghouse Hanford Company

P.O. Box 1970 Richland, WA 99352

A Subsidiary of Westinghouse Electric Corporation

Prepared for the U.S. Department of Energy under Contract No. DE-AC1476FF02170. 


\section{DISCLAIMER}

This report was prepared as an account of work sponsored by an agency of the United States Government. Neither the United States Government nor any agency Thereof, nor any of their employees, makes any warranty, express or implied, or assumes any legal liability or responsibility for the accuracy, completeness, or usefulness of any information, apparatus, product, or process disclosed, or represents that its use would not infringe privately owned rights. Reference herein to any specific commercial product, process, or service by trade name, trademark, manufacturer, or otherwise does not necessarily constitute or imply its endorsement, recommendation, or favoring by the United States Government or any agency thereof. The views and opinions of authors expressed herein do not necessarily state or reflect those of the United States Government or any agency thereof. 


\section{DISCLAIMER}

Portions of this document may be illegible in electronic image products. Images are produced from the best available original document. 


\title{
A REVIEW OF WATER
}

RESOURCE POTENTIAL FOR DEVELOPING

GEOTHERMAL RESOURCE SITES IN

THE WESTERN UNITED STATES

J. C. Sonnichsen, Jr.

\section{ABSTRACT}

\begin{abstract}
Water resources at 28 known geothermal resource areas (KGRAs) in the Western United States are reviewed. Primary emphasis is placed upon examination of the water resources, both surface and ground, that exist in the vicinity of the KGRAs located in the southwestern states of California, Arizona, Utah, Nevada, and New Mexico. In most of these regions water has been in short supply for many years and consequently a discussion of competing demands is included to provide an appropriate perspective on overall usage. A discussion of the water resources in the vicinity of KGRAs in the States of Montana, Idaho, Oregon, and Washington are also included.
\end{abstract}


Abstract

Figures

ix

Tables

ix

1.0 SUMMARY

$2.0 \div \quad$ INTRODUCTION

3.0 WATER RESOURCES FOR DEVELOPING GEOTHERMAL SITES

IN CAL IFORNIA

3.1 NORTHWEST CALIFORNIA

3.1.1 Geyser KGRA

3.1.1.1 Geothermal Resource Characteristics

3.1.1.2 Water Resources

3.1.1.3 Competing Water Demands.

3.1.2 Glass Mountain KGRA

3.1.2.1 Geothermal Resource Characteristics

3.1.2.2 Water Resources

3.1.2.3 Competing Water Demands

3.2 NORTHEASTERN CALIFORNIA 22

3.2.1 Surprise Valley KGRA 22

3.2.1.1 Geothermal Resource Characteristics 22

3.2.1.2 Water Resources 23

3.2.1.3 Competing Water. Demands . . : $\quad 27$

3.2.2 Lassen KGRA _. . . . . . . . . $\quad 27$

3.2.2.1 Geothermal Resource Characteristics. 27

3.2.2.2 Water Resources 28

3.2.2.3 Competing Water Demands 30

3.3 CENTRAL AND SOUTHERN CALIFORNIA - 30

3.3.1 Mono-Long Valley KGRA 30

$\begin{array}{ll}\text { 3.3.1.1 Geothermal Resource } & \\ \text { Characteristics } & 30\end{array}$

3.3.1.2 Water Resources 31

3.3.1.3 Competing Water Demands 33 


\section{CONTENTS (Cont'd)}

3.3.2 Imperial Valley KGRA

\subsubsection{Geothermal Resource}

Characteristics

34

3.3.2.2 Water Resources

36

3.3.2.3 Competing Water Demands

42

3.3.3 Coso KGRA

\subsubsection{Geothermal Resource} Characteristics

3.3.3.2 Water Resources

3.3.3.3 Competing Water Demands

4.0 WATER RESOURCES FOR DEVELOPING GEOTHERMAL SITES IN ARIZONA

4.1 CHANDLER KGRA 45

4.1.1 Geothermal Resource Characteristics $\quad 45$

4.1.2 Water Resources $\quad 45$

4.1.3 Competing Water Demands 47

$\begin{array}{lll}4.2 & \text { SAFFORD KGRA } & 47\end{array}$

$\begin{array}{ll}5.0 & \text { WATER RESOURCES FOR DEVELOPMENT OF GEOTHERMAL } \\ \text { SITES IN UTAH } & 49\end{array}$

$\begin{array}{lll}5.1 & \text { THERMO KGRA } & 49\end{array}$

5.1.1 Geothermal Resource Characteristics $\quad 49$

5.1.2 Water Resources 49

$\begin{array}{lll}5.2 & \text { ROOSEVELT HOT SPRINGS KGRA } & 50\end{array}$

5.2.1 Geothermal Resource Characteristics $\quad 50$

5.2.2 Water Resources 50

5.3 COVE FORT-SULPHERDALE KGRA 50

5.3.1 Geothermal Resource Characteristics 51

5.3.2 Water Resources 51 
5.4 WATER RESOURCES

51

5.4.1 Surface Water Resources (Thermo, Rooseve1t)

51

5.4.2 Surface Water Resources (Cove Fort-Sulphurdale) 52

5.4.3 Groundwater Resources

5.4.4 Competing Water Demands

6.0 WATER RESOURCES FOR DEVELOPMENT OF GEOTHERMAL SITES IN NEVADA

6.1 STEAMBOAT SPRIIIGS KGRA 55

6.1.1 Geothermal Resource Characteristics $\quad 55$

6.1.2 Water Resources 55

6.1.3 Competing Water Demands 56

$\begin{array}{lll}6.2 & \text { BRADY HOT SPRINGS KGRA } & 57\end{array}$

6.2.1 Geothermal Resource Characteristics 57

6.2.2 Water Resources 57

6.2.3 Competing Water Demands 58

6.3 LEACH KGRA 58

6.3.1 Geothermal Resource Characteristics 58

6.3.2 Water Resources 58

6.3.3 Competing Water Demands 58

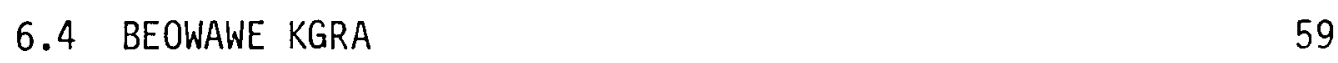

6.4.1 Geothermal Resource Characteristics $\quad 59$

6.4.2 Water Resources : . 59

6.4.3 Competing Water Demands 60

7.0 WATER RESOURCES FOR DEVELOPMENT OF GEOTHERMAL SITES IN NEW MEXICO $\quad 61$

7.1 VALLES CALDERA KGRA 61

7.1.1 Geothermal Resource Characteristics 61

7.1.2 Water Resources 62

7.1.3 Competing Water Demands 62 


\section{CONTENTS (Cont'd)}

Page

8.0 WATER RESOURCES FOR DEVELOPMENT OF GEOTHERMAL SITES IN MONTANA

9.0 WATER RESOURCES FOR DEVELOPMENT OF GEOTHERMAL SITES IN IDAHO

9.1 RAFT RIVER KGRA $\quad 65$

9.1.1 Geothermal Resource Characteristics 65

9.1.2 Water Resources 65

9.2 BRUNEAU - GRANDVIEW KGRA 66

9.2.1 Geothermal Resource Characteristics 66

9.2.2 Water Resources 67

9.3 WEISER - CRANE CREEK KGRA 67

9.3.1 Geothermal Resource Characteristics 68

9.3.2 Water Resources 68

10.0 WATER RESOURCES FOR DEVELOPMENT OF GEOTHERMAL SITES
IN OREGON

$\begin{array}{lll}10.1 & \text { VALE HOT SPRINGS KGRA } & 69\end{array}$

10.1.1 Geothermal Resource Characteristics 69

10.1.2 Water Resources 69

$\begin{array}{lll}10.2 & \text { ALVORD KGRA } & 70\end{array}$

10.2.1 Geothermal Resource Characteristics 70

10.2.2 Water Resources $\quad 70$

11.0 WATER RESOURCES FOR DEVELOPMENT OF GEOTHERMAL SITES IN WASHINGTON

12.0 REFERENCES

DISTRIBUTION

Distr-1 


\section{FIGURES}

Figure

1 Steam Expansion Process for Vapor-Dominated

Convective Resource

$2 \quad$ Flash-Steam Process for Liquid Dominated

Convective Resource

3 Binary System; Secondary Working Fluid Expansion for Liquid-Dominated Convective Resources

$4 \quad$ Location of KGRAs

5 Location of Aggregated Subareas (ASAs)

\section{TABLES}

Table

$1 \quad$ Water Resource Requirements for Developing Geothermal Energy

2 Water Resource Requirements for Developing Geothermal Energy

3 Mean Monthly Flow of Russian River Near Healdsburg (cubic feet per second)

4 Mean Monthly Flow of Cache Creek Near Lower Creek (cubic feet per second)

5 Mean Monthly Flow of South Fork Pit River (cubic feet per second)

6 Mean Monthly Flow of North Fork Pit River (cubic feet per second)

7 Monthly Flow Statistics for Butte Creek (cubic feet per second)

8 Mean Monthly Flow of All-American Canal Near Imperial Dam (cubic feet per second)

9 Flow Statistics for the New River (cubic feet per second)

10 Monthly Flow Statistics for the Alamo River (cubic feet per second) 
In this study the water resources at 28 known geothermal resource areas (KGRA) in the western United States are reviewed. Primary emphasis is placed upon examination of the water resources, both surface and ground, that exist in the vicinity of the KGRAs located in the southwestern states of California, Arizona, Utah, Nevada, and New Mexico. In most of these regions, water has been in short supply for many years and consequently a discussion of competing demands is included to provide an appropriate perspective on overall usage. A discussion of the water resources in the vicinity of KGRAs in Montana, Idaho, Oregon, and Washington is also included to help round out the picture in the western United States.

In terms of water resource management, the development of a specific geothermal site is an extremely complex subject. A unique characteristic of liquid-convective geothermal resources is that the resource can of ten satisfy its own cooling water requirement. The quality of geothermal water, type of cooling, seismicity and subsidence characteristics, and water usage tradeoffs are a few of the parameters that must be considered when defining a water management $\mathrm{pl}$ an. Development of specific water management $\mathrm{pl}$ ans for the KGRAs reviewed was beyond the scope of the study. However, the discussion and data provided herein, although conceptually of a generic nature, do to a large extent delineate the availability of specific resources and as such imply potential patterns of water usage for purposes of geothermal development.

Cooling water requirements are assumed to range from zero to 6000 gal per minute per $100 \mathrm{MWe}$. Generally speaking, the cooling water requirements for developing geothermal energy are three to five times greater than the cooling water requirements for comparably sized conventional steam electric power plants. Obviously, in water short regions the development of geothermal energy will be limited by the availability of fresh water resources and will require usage of geothermal water for purposes of cooling or regional augmentation. The use of brine water, both surface and groundwater, and dry type cooling will receive increasing attention in future years. 
$\theta$

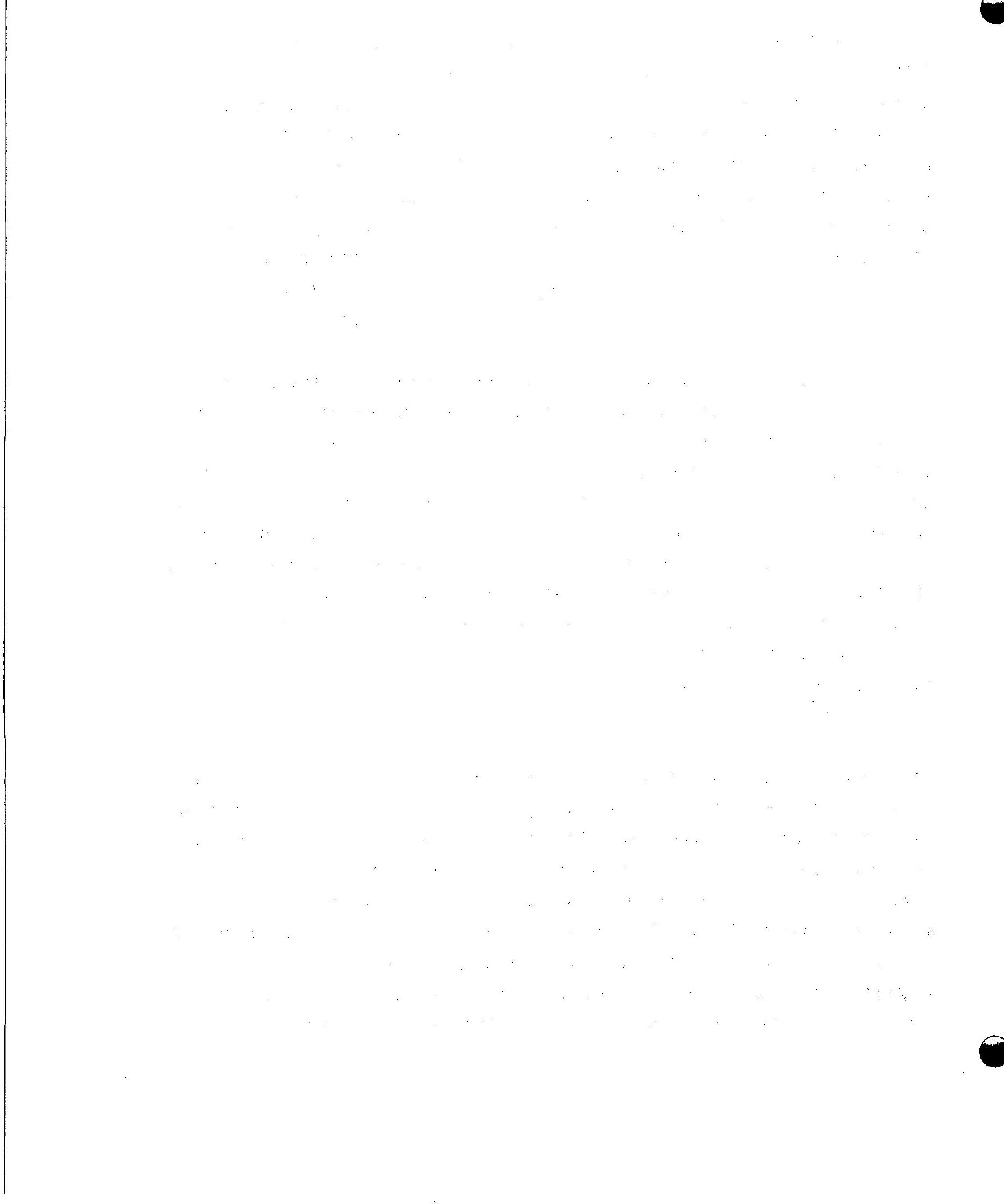

• 


\section{$2.0 \quad$ INTRODUCTION}

The presence of geothermal energy resources can be largely explained by $\mathrm{pl}$ ate tectonics or the movement of the earth's crust. In regions where the plates come into contact, the areas are characterized by earthquakes, volcanic activity, and high heat flows. The Pacific and North American plates come together along the Pacific coast. As a result, geothermal anomalies at or near the earth's surface are fairly common in the west.

Geothermal energy can be used directiy as heat for space heating, etc., or if the enthalpy of the resource is high enough, the energy can be efficiently converted into electrical energy. The majority of the world's geothermal resources do not possess sufficient energy to be used for purposes of electrical power generation, but are sufficient for space heating, agricultural application, industrial process heat, and air conditioning.

The 1 argest geothermal power facility in the world is located at the Geysers in northern California. The Geysers geothermal resource is a vapor dominated system, thereby permitting steam to be piped directiy to a turbogenerator. However, vapor-dominated systems similar to that existing at the Geysers are rare. Liquid dominated systems are more common and are found in a number of locations in the west. Estimates by the U.S. Geological Survey indicate that 1560 quads $\left(1650 \times 10^{18} \mathrm{~J}\right)$ of useful energy are present in reservoirs of 215 identified hydrothermal convection systems greater than $194^{\circ} \mathrm{F}\left(90^{\circ} \mathrm{C}\right)$ in the United States to a depth of $9843 \mathrm{ft}(3 \mathrm{~km}).(1)$

The evaporative cooling water requirements associated with dissipating waste heat are directly proportional to the quantity of heat dissipated. Geothermal fluids typically have low enthalpy values compared to other energy sources used for generating steam. It follows from the 1 aws. of thermodynamics that energy sources possessing low enthalpy result in a low overall thermodynamic cycle efficiency; consequently, large quantities of heat are rejected for each megawatt of net power generated. Consistent with 
evaporative cooling technology, the evaporative c0oling water requirements for geothermal power plants are greater than those for comparably sized conventional generating $\mathrm{plants.}$

Geothermal resources are categorized into four distinct types: vapordominated convective, liquid-dominated convective, geopressure, and hot dry rocks. The thermal properties of each are different; consequently, the specific characteristics of the thermodynamic cycles that have been proposed for purposes of extracting geothermal energy are different.

A schematic diagram for a vapor-dominated convective resource steam cycle is shown in Figure 1. (2) The vapor flows from the production well to the turbine generator. Exhaust steam from the turbine generator is condensed and the condensate can be used as make-up water for the cooling tower. As shown in Figure 1, cooling tower blowdown is reinjected as recharge.

Several power cycles are being considered for extraction of energy from liquid dominated resources. The two power cycles receiving the most attention are the flash steam process, and the binary process that uses a secondary working fluid (isobutane, freon, etc). Condenser cooling is required for both processes. A schematic diagram for a flash steam expansion process is provided in Figure 2. (2) As shown in Figure 2, the resource is pumped from a production well to a flash drum, where the steam is drawn of $f$ to operate the turbine generator. The geothermal fluid is returned and the condensate used as cooling tower makeup.

The technology for flashed-steam geothermal power $\mathrm{plants}$ has been we 11 developed or established. In New Zealand, Mexico, and Japan, a total of 600 MWe of installed capacity has been developed using flash steam conversion. (3) Development has lagged in the United States due to the exploitation of other forms of low cost energy. 


\section{EVAP. \& DRIFT}

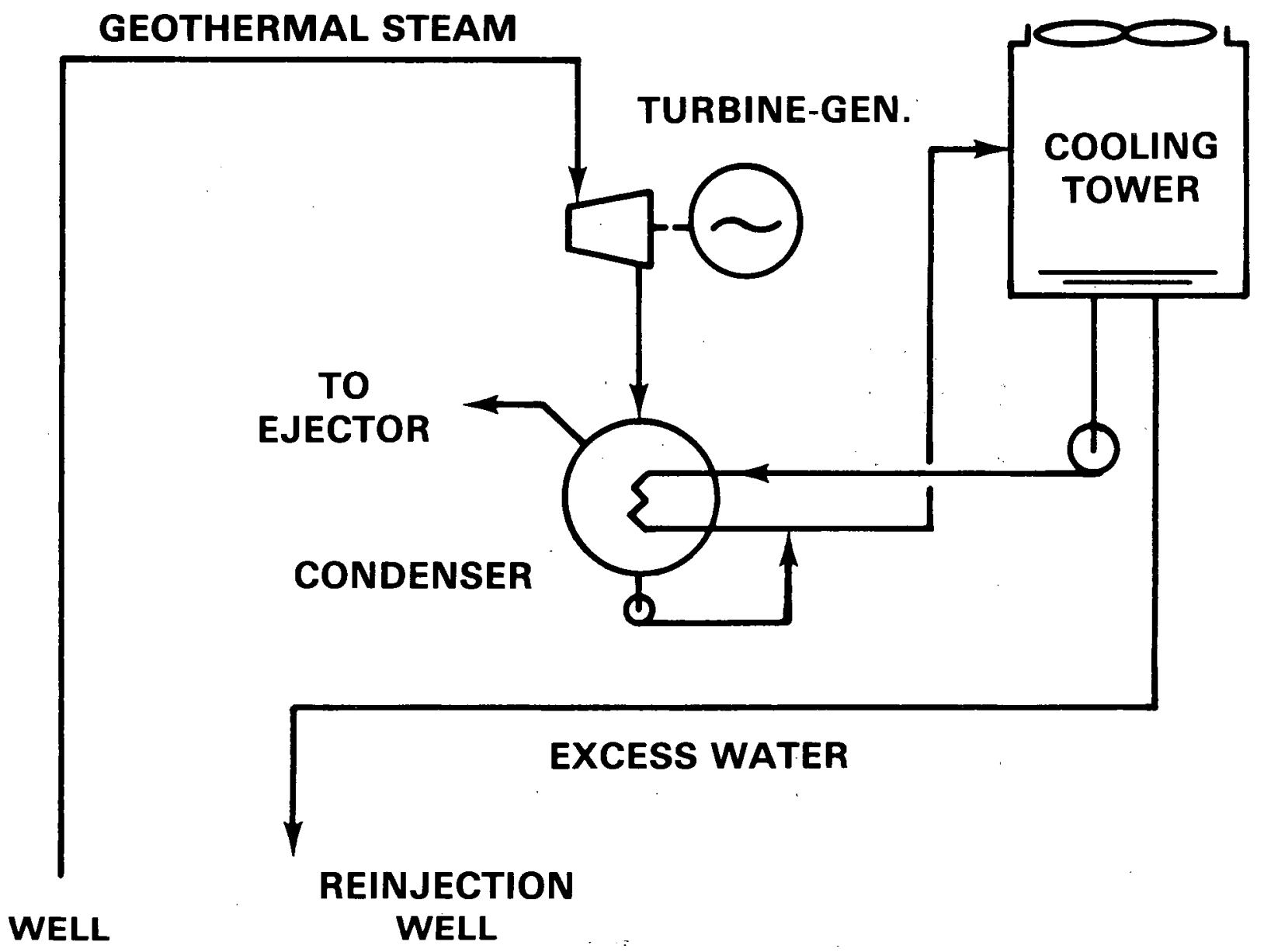

HEDL 8005-108.2

FIGURE 1. Steam Expansion Process for Vapor-Dominated Convective Resource. Neg $8006036-4$ 
EVAP. \& DRIFT

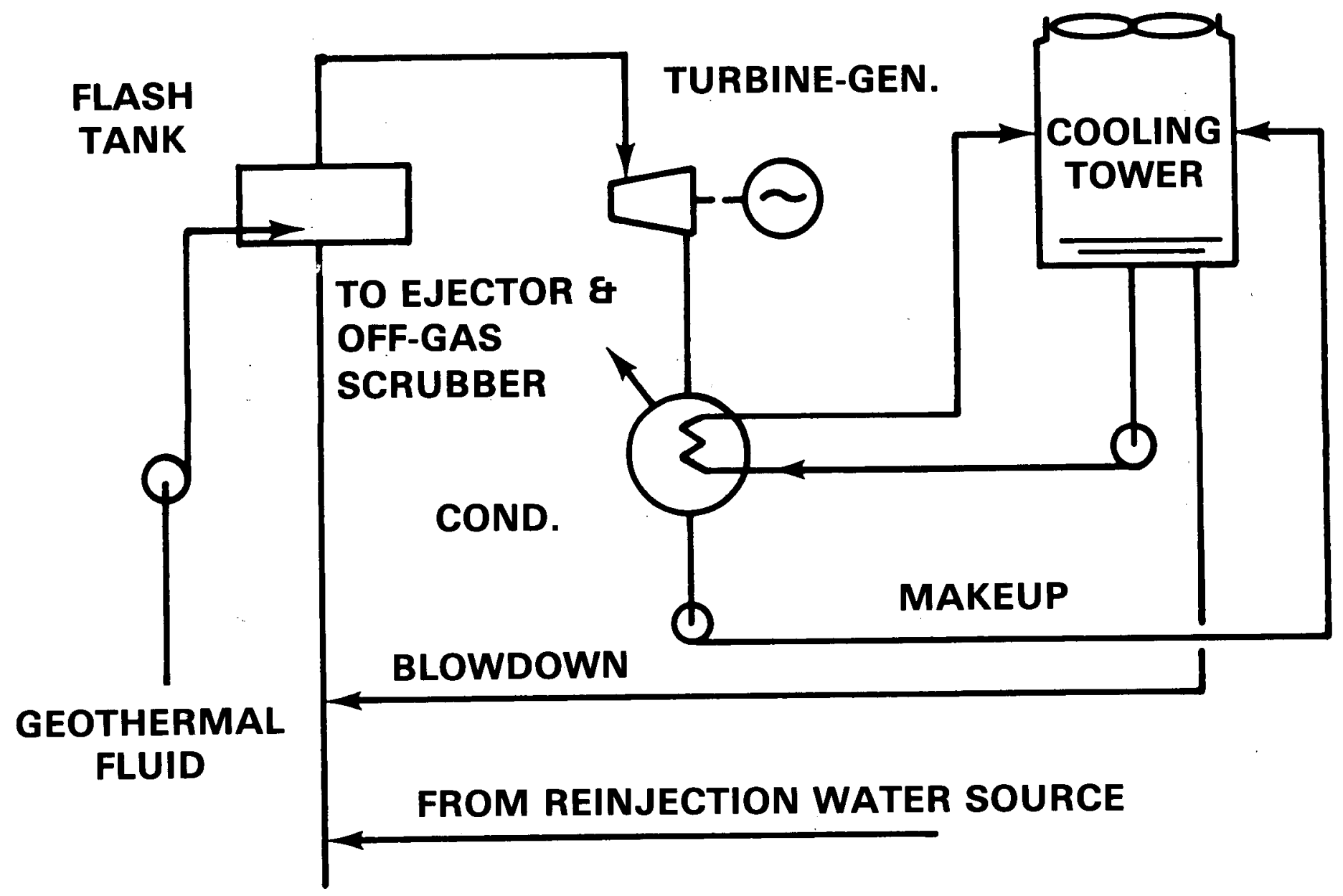

HEDL $8005-108.3$

FIGURE 2. Flash-Steam Expansion Process for Liquid Dominated Convective Resource.

Neg 8006036-1 
If the temperature of the geothermal resource is less than approximately $360^{\circ} \mathrm{F}\left(182^{\circ} \mathrm{C}\right)$, steam production by flashing becomes impractical. Development of the binary system is being pursued for purposes of producing energy from these lower enthalpy geothermal resources. Using the binary cycle, the geothermal resource does not come into contact with the turbine or condenser. An 11 MWe demonstration binary-cycle geothermal unit at East Mesa California is scheduled for startup during late 1979. A 5 MWe binarycycle demonstration $\mathrm{plan}$ is being constructed at Raft River, Idaho, to examine the feasibility of developing low enthalpy liquid dominated convective resources.

Use of a binary or secondary fluid for converting liquid dominated geothermal energy is shown in Figure $3 .{ }^{(2)}$ Liquid is pumped from the production well through a heat exchanger, where the thermal energy is transferred to a secondary working fluid. The geothermal liquid is reinjected or used for makeup water depending upon the specific design, water quality, and water resource management $\mathrm{plan}$. Water resource requirements will vary depending upon the design and $\mathrm{plan}$ selected.

Zones of geothermal - geopressure exist offshore along the continental shelf. Geothermal - geopressure zones are caused by variable sediment loads deposited offshore. As younger sediments are deposited over older segments, large quantities of sand of ten sink into older mud and clay formations. The penetration of these sands results in the formation of sand filled zones, which become pressured during subsequent compaction. A characteristic of these pressurized zones is the presence of methane or natural gas dissolved in the brine.

Research is currentiy underway attempting to determine the feasibility of developing geothermal-geopressure zones. Test wells will be drilled and instrumented to define the constituents and characteristic properties of the geothermal fluids. Additional research will be required to determine the most efficient means of generating electrical energy from the geothermal fluids. 
EVAP. \& DRIFT

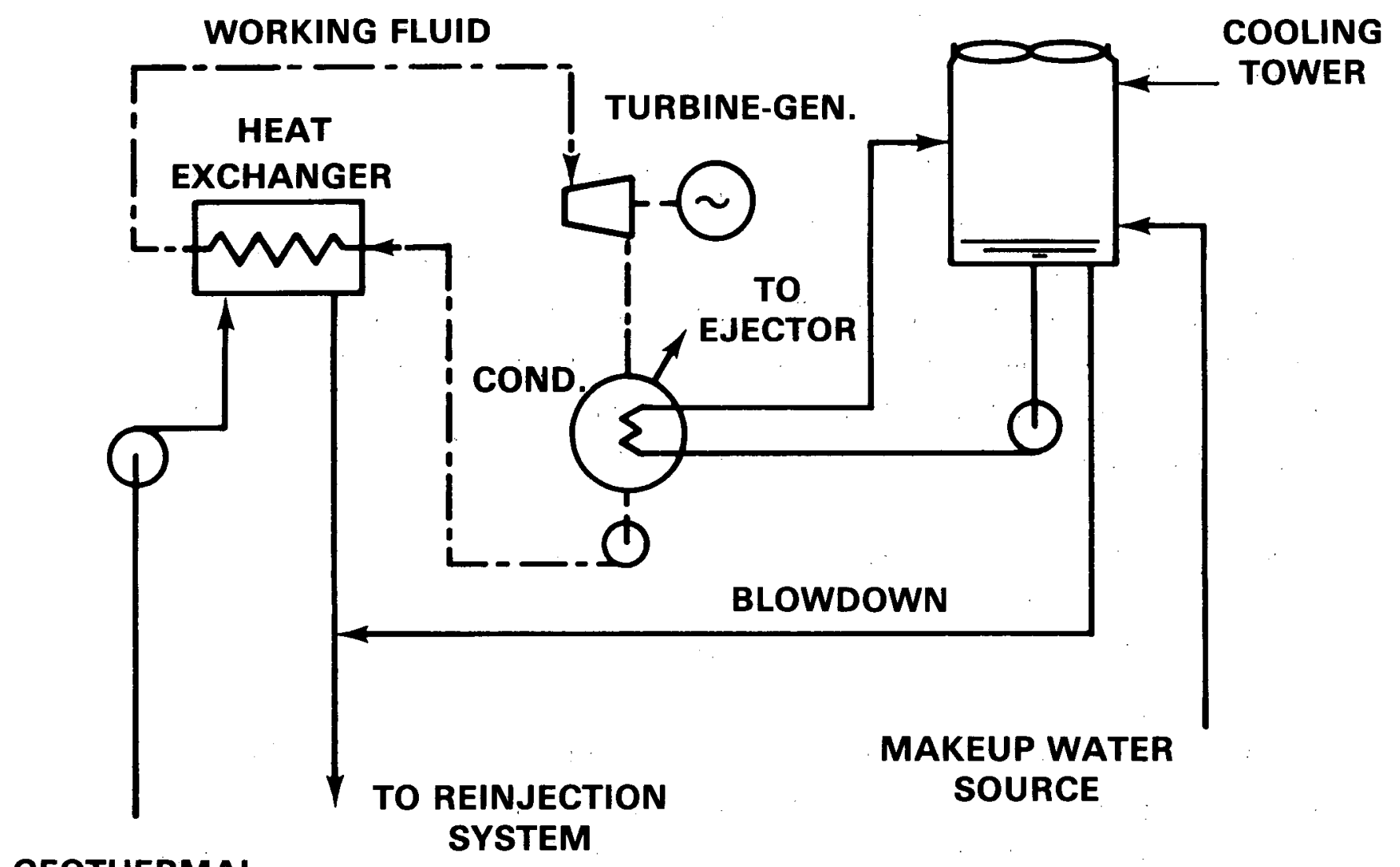

GEOTHERMAL

FLUID

HEDL 8005-108.1

FIGURE 3. Binary System; Secondary Working Fluid Expansion for LiquidDominated Convective Resources.

Neg 8006036-3 
In terms of quantifying water requirements for developing geothermal energy, a generalized water balance can be formulated as follows:

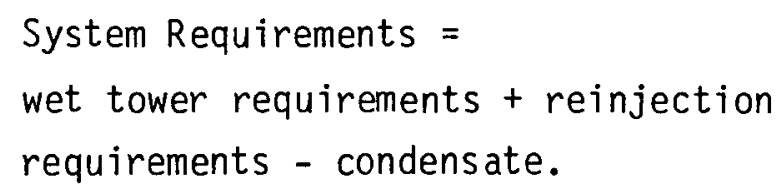

Theoretically, if the reinjection requirements are negligible, the condensate that is recovered from condensing the vapor will be sufficient to offset the cooling tower makeup requirements, provided the chemistry of the geothermal water is compatible with the materials used in the cooling system.

Tables 1 and 2 compare estimated water requirements for converting geothermal resources. Table 1 summarizes the evaporation cooling water makeup water conditions for a flash-steam expansion process. An overall conversion cycle efficiency of $10 \%$ was assumed. Makeup water requirements were evaluated for various types of cooling, assuming that $75 \%$ of the waste heat was removed through the process of evaporation. No adjustment for blowdown requirement was included, due to the tremendous potential variation in the quality of the cooling water. Furthermore, it was assumed that $80 \%$ of the wet tower makeup requirements could be provided through the recovery of the geothermal resource condensation. In reality, the amount of water recovered will depend upon a number of variables, including water management consideration, water quality consideration, materials, and environmental concerns. Table 2 provides data similar to Table 1 on cooling water requirements, for a binary type cooling system, assuming that $100 \%$ of the geothermal liquid is used as recharge. Subsidence considerations could require a $100 \%$ return of the geothermal fluid or recharge of similar fluid. Waste water or water of poor quality might be substituted and reinjected in exchange for the geothermal water if the geothermal water is of a quality suitable for 
TABLE 1

COOLING WATER MAKEUP REQUIREMENTS CONSIDERING THE RECOVERY AND USE OF GEOTHERMAL LIQUID CONDENSATE

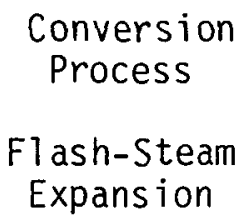

$\begin{array}{cc}\begin{array}{c}\text { Cycle } \\ \text { Efficiency }\end{array} & \begin{array}{c}\text { Type of } \\ \text { Cooling }\end{array} \\ 10 \% & \text { Wet Tower } \\ & 50 \% \text { Wet } / \text { Dry } \\ & \text { Dry Tower }\end{array}$

Evaporative
Makeup
Reqt.
4630
2315
0

Recovery Condens ate (gpm/100 MWe)

Gain
Net
$($ gpm $/ 100$ MWe $)$
+306
+2621
+4936

TABLE 2

COOLING WATER MAKEUP REQUIREMENTS ASSUMING NO RECOVERY OF GEOTHERMAL RESOURCE FOR PURPOSES OF COOLING

$\begin{array}{cccccc}\begin{array}{c}\text { Conversion } \\ \text { Process }\end{array} & \begin{array}{c}\text { Cycle } \\ \text { Efficiency }\end{array} & \begin{array}{c}\text { Type of } \\ \text { Cooling }\end{array} & \begin{array}{c}\text { Evaporative } \\ \text { Makeup } \\ \text { Reqt. }\end{array} & \begin{array}{c}\text { Recovery } \\ \text { Condensate } \\ \text { (gpm/100 MWe) }\end{array} & \begin{array}{r}\text { Gain } \\ \text { Net } \\ \text { (gpm/100 MWe) }\end{array} \\ \begin{array}{l}\text { Secondary } \\ \text { Working Fluid }\end{array} & 10 \% & \text { Wet Tower } & 4630 & 0 & -4630 \\ & & 50 \% \text { Wet/Dry } & 2315 & 0 & -2315 \\ & & \text { Dry Tower } & 0 & 0 & 0\end{array}$


other uses. The exact water management plan will depend upon the specific geothermal resource characteristics, existing water demands and usage patterns, and legal considerations.

Figure 4 shows the location of the 28 KGRAs reviewed in this study. Of primary interest are the KGRAs located in California, Arizona, Utah, Nevada, and New Mexico. Ten of the KGRAs reviewed in this study are located in California; four in Nevada, three in Utah, two in Arizona and one in New Mexico. The remaining eight KGRAs reviewed are located in Oregon, Idaho, Montana and Washington. 


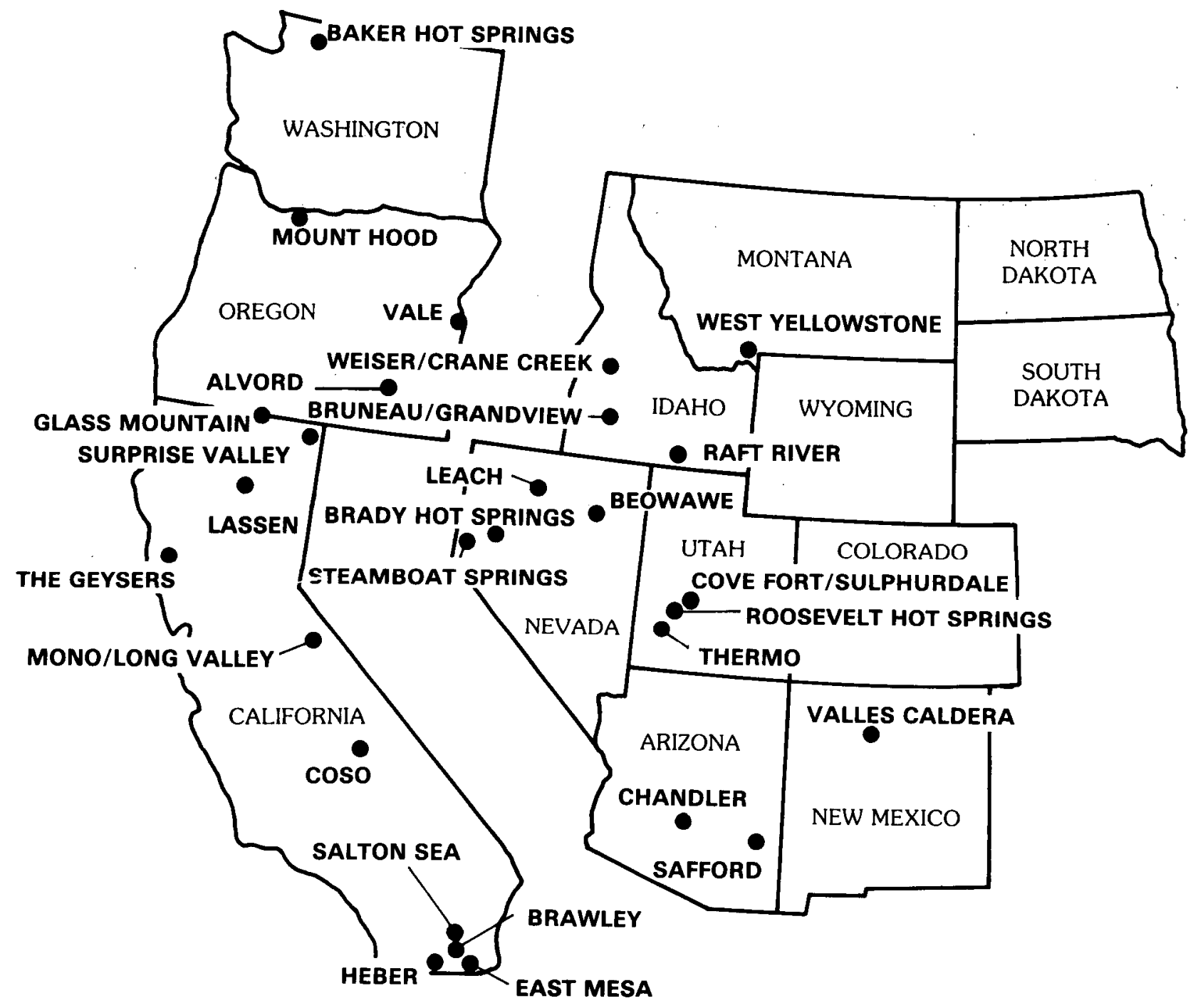

HEDL 8005-I.8

FIGURE 4. Location of KGRAs.

Neg 8006036-5 
3.0 WATER RESOURCES FOR DEVELOPMENT OF GEOTHERMAL SITES IN CALIFORNIA

3.1 NORTHWEST CALIFORNIA

Northwestern California possesses two KGRAs: The Geysers and Glass

Mountain. The Geysers site is located approximately 30 miles north of Santa Rosa, in Sonoma County. The Glass Mountain site is located in eastern Siskiyou County near Yreka.

\subsubsection{The Geysers KGRA}

The Geysers is the most developed geothermal resource site in the world. Over 660 MWe of capacity currently exists at the site and an additional 800 MWe of capacity is forecasted to be added over the next few years. The development scenario prepared by the Department of Energy (DOE) calls for more than 2000 MWe of capacity to be developed prior to $1990 .{ }^{(4)}$ Field limits are currently estimated at 2500 MWe.

Geothermal power generation in the United States started in 1960. In 1956, a drilling program was initiated that resulted in six production wells with a capacity of about $300,000 \mathrm{lb} / \mathrm{hr}$ of steam at about 115 psig with a slight superheat. In 1958, Pacific Gas and Electric began construction of a 12-MWe generating $\mathrm{plant}$ that began commercial operation in 1960 . Since that time, additional generating units have been added; the current total is 11 units generating 663 MWe. During 1980 an additional 245 MWe of capacity are planned for installation. (5)

\subsubsection{Geothermal Resource Characteristics}

The Geysers KGRA is categorized as a vapor-dominated convective resource. Geothermal steam at The Geysers is slightly superheated with a constant enthalpy of $1200 \mathrm{Btu} / \mathrm{lb}$. At $100 \mathrm{psig}$ the temperature of the resource is $355^{\circ} \mathrm{F}\left(179^{\circ} \mathrm{C}\right)$ compared to $338^{\circ} \mathrm{F}\left(170^{\circ} \mathrm{C}\right)$ for saturated condition. ${ }^{(5)}$ 
The system diagramed in Figure 1 is used at The Geysers. Direct contact condensers are used on several of the units. The direct contact condensers are mounted directly below the turbine exhaust, permitting the cooling water to flow into the condenser by vacuum suction. No "outside" water is required for the cooling tower operation. The steam condensate provides more water than is required for makeup. Approximately $20 \%$ of the condensate remains after providing the necessary cooling tower makeup.

A liquid dominated convective resource is located around the periphery of the KGRA. In the development of The Geysers KGRA, one well, which intersected a high enthalpy liquid resource, was drilled near Clear Lake. This resource has not been developed to date.

The DOE development scenario calls for 1000 MWe of additional installed capacity to be developed from the liquid-dominated resource. The resource is $\mathrm{classified}$ as a high enthalpy liquid with a temperature range of $446^{\circ} \mathrm{F}$ to $482^{\circ} \mathrm{F}\left(230^{\circ} \mathrm{C}\right.$ to $\left.250^{\circ} \mathrm{C}\right)$.

\subsubsection{Water Resource}

Generally speaking, no water shortages are anticipated in developing The Geysers KGRA. At The Geysers KGRA vapor-dominated resource, condensation of the steam results in a surplus of water.

To develop the liquid-dominated resource, some cooling water may be required. If recharge is not required, the flash steam expansion process could be used. Using this process, the recovery of condensate could be sufficient to offset the wet cooling tower water requirements. If reinjection or recharge is required, use of wet evaporative cooling tower technology could result in a total consumptive water use requirement of approximately 4000 gal per minute per 100 MWe. 
Surface Water Resources -- Considerable surface water resources exist in the general area of The Geysers KGRA. Major surface water resources include the Russian River and its tributaries, Cache Creek, and Clear Lake. Maximum surface water temperatures are generally less than $68^{\circ} \mathrm{F}\left(20^{\circ} \mathrm{C}\right)$ and water quality measured as total dissolved solids (TDS) in less than $1000 \mathrm{ppm}$.

Russian River -- The Russian River flows along the west side of the KGRA. The Russian River drains an area of approximately $800 \mathrm{sq}$ mi above the lower boundary of the geothermal resource region. At Healdsburg, California (nearest gaging station) ${ }^{(6)}$ the mean annual discharge of the Russian River is $1472 \mathrm{ft}^{3} / \mathrm{s}$.* A statistical summary of the $\mathrm{flow}$ characteristics for the Russian River at Healdsburg is provided in Table 3 . The mean annual discharge of this river at Healdsburg is $1.06 \times 10^{6}$ acre-ft/year. (6)

Major diversions and impoundment above Healdsburg are minimal. Total irrigation diversion is less than 20,000 acre-ft/year. The only major impoundment above Healdsburg is Lake Mendocino, sixty-three miles upstream. The drainage area above the reservoir is approximately $100 \mathrm{sq} \mathrm{mi}$ and the volume of the reservoir is less than 100,000 acre-ft. Therefore, control of the Russian River at Healdsburg should be relatively unaffected by the operation of Lake Mendocino during normal water years.

Cache Creek -- Cache Creek is located to the east of the KGRA. The resource flows east into the Sacramento River system. By comparison, Cache Creek is smaller than the Russian River, with an average annual discharge of 686 $\mathrm{ft}^{3} / \mathrm{s}$ at Capay, some thirty miles east of the KGRA. The average annual flow rate of Cache Creek at Lower Lake, approximate east boundary of the KGRA, is $366 \mathrm{ft}^{3} / \mathrm{s}$. A statistical summary of mean monthly flow data is provided in Table 4. Flow of the resource is completely regulated by the operation of Clear Lake. Heavy irrigation demands are placed upon the flow of Cache Creek. ${ }^{(6)}$

*Conversion factors $\mathrm{ft}^{3} / \mathrm{s}=450 \mathrm{gpm}$ acre-ft/year $=.618 \mathrm{gpm}$. 
TABLE 3

MEAN MONTHLY FLOW OF RUSSIAN RIVER NEAR HEALDSBURG (cubic feet per second)

\begin{tabular}{lrr}
\multicolumn{1}{c}{ Month } & Flow \\
October & & 42 \\
November & & 642 \\
December & & 3120 \\
January & & 4715 \\
February & & 4785 \\
March & 2418 \\
April & 1516 \\
May & 688 \\
June & 297 \\
July & 182 \\
August & 177 \\
September & 207
\end{tabular}


TABLE 4

MEAN MONTHLY FLOW OF CACHE CREEK NEAR LOWER LAKE (cubic feet per second)

$\begin{array}{lr}\text { Month } & \text { Flow } \\ \text { October } & 17 \\ \text { November } & 2 \\ \text { December } & 33 \\ \text { January } & 770 \\ \text { February } & 1055 \\ \text { March } & 813 \\ \text { April } & 586 \\ \text { May } & 315 \\ \text { June } & 411 \\ \text { July } & 436 \\ \text { August } & 380 \\ \text { September } & 181\end{array}$


Clear Lake -- Clear Lake is a natural lake that is regulated by gates at the outlet end. Clear Lake is a large lake, estimated surface area $50 \mathrm{sq} \mathrm{mi}$, located in Lake County, California. The storage capacity of Clear Lake exceeds $1 \times 10^{6} \mathrm{Ac}-\mathrm{ft}$. The lake is used primarily for recreational purposes. The lake is located within 80 miles of San Francisco and access to the lake is good. Highway 101 passes within 10 miles of the lake on the west side.

Groundwater -- In the Sacramento River Valley, groundwater occurs primarily in alluvium-filled valleys. Groundwater has been extensively explored but not developed in the vicinity of the Geysers KGRA. Five major groundwater basins (Clear Lake, Russian River, Sonoma Valley, Napa and Petaluma) exist near the KGRA. The total estimated groundwater in-storage in the area is 14,660,000 acre-ft, composed of the following: Clear Lake 200,000 acre-ft, Russian River 9,300,000 acre-ft, Sonoma Valley 2,760,000 acre-ft, Napa Valley 300,000 acre-ft, and Petaluma 2,100,000 acre-ft. ${ }^{(18)}$ The range in TDS is 71 to $294 \mathrm{ppm}$. A yield of 500 gal per minute can be obtained.

\subsubsection{Competing Water Demands}

The Geysers KGRA is located in Water Resource Subregion ASA 1804. (9) Figure 5 is a map showing the 99 ASA for the 48 contiguous states. In assessing water supply and demand requirements, an analysis was performed to identify the consumptive use during the critical time of the year. The critical time was defined as the period of the year when the total water demand utilizes the greatest proportion of the supply. Surface water supplies were based upon monthly $95 \%$ discharge exceedence statistics. The critical water supply month for ASA 1804 is September, and the critical surface supply (CSS) is 1000.3 million gallons per day (Mgd). (10) The 1975 consumptive demand was estimated to be 933 Mgd representing over $90 \%$ consumptive utilization of the surface water resource. The consumptive use is expected to exceed $100 \%$ of the CSS by 1985 . 


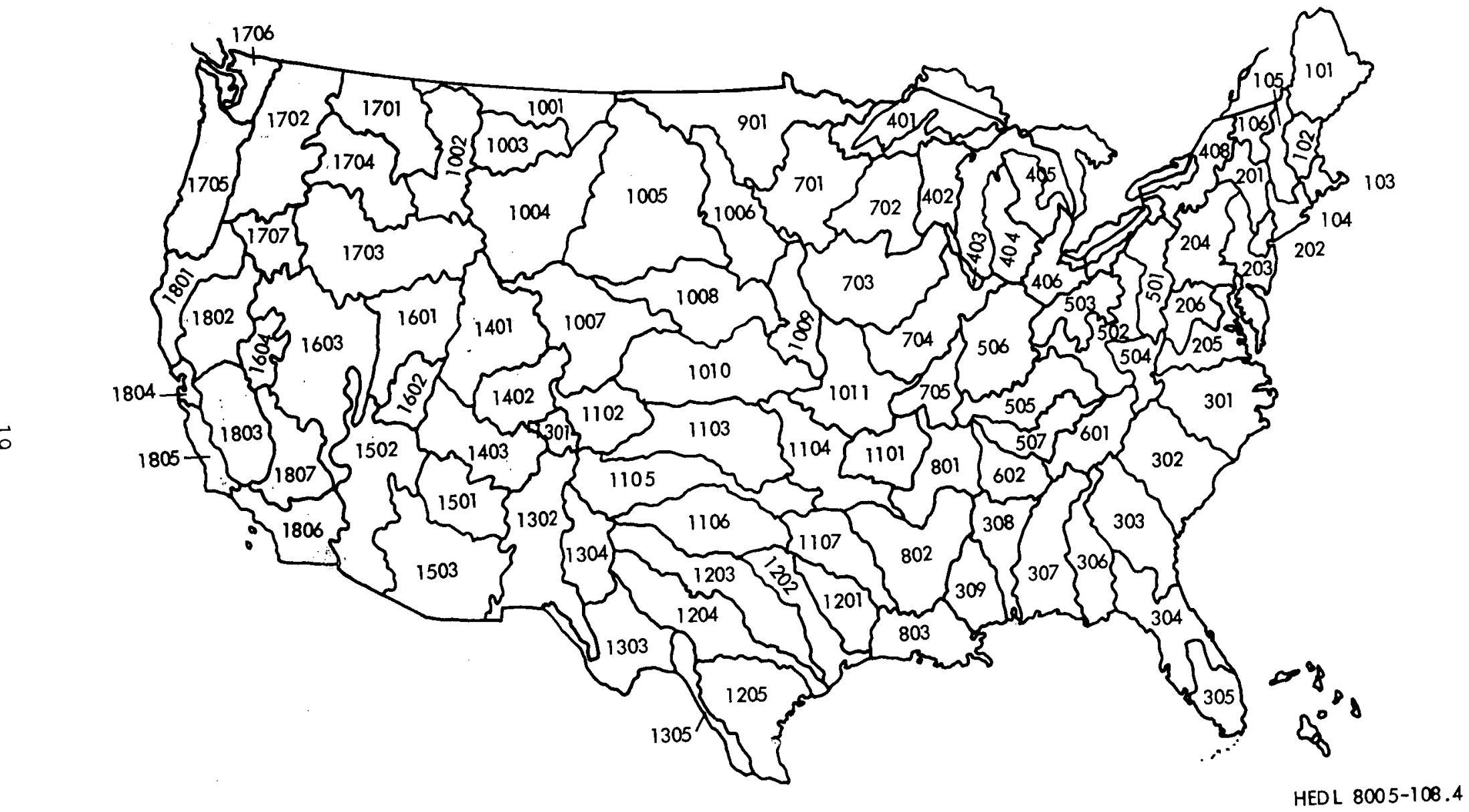

FIGURE 5. Location of Aggregated Subareas (ASA). 
The primary use of the water is for irrigation. Over $50 \%$ of the consumptive use results from irrigation. The next largest usage is for providing potable water. The 1975 consumptive usage resulting from domestic supply was over $260 \mathrm{Mgd}$.

Lack of storage capability at Clear Lake results in an overspill of 107,600 acre-ft, which is presently unappropriated. (11) Most spillage occurs during the rainy season of 0ctober through March. Consequently, storage facilities would be required to preserve its use during other periods of the year.

\subsubsection{Glass Mountain KGRA}

The Glass Mountain KGRA is located in the eastern part of Siskiyou County in northern Cal ifornia near the 0regon border. The Glass Mountain KGRA is classified as a liquid-dominated resource.

\subsubsection{Geothermal Resource Characteristics}

The Glass Mountain KGRA is located on the eastern side of Siskiyou County along the western boundary of the Modoc National Forest. The KGRA covers 33,500 acres. The Department of Energy development scenarios call for 50 MWe of generating capacity to be installed over the next 30-yr period. Characterization of the site has been slow. Geothermal resource temperatures are estimated to exceed $392^{\circ} \mathrm{F}\left(200^{\circ} \mathrm{C}\right)$. Development of the resource could utilize either a flash-steam process or a binary cycle. Water requirements are estimated to range from 4000 to $5000 \mathrm{gal} / \mathrm{min} / 100 \mathrm{MWe}$.

\subsubsection{Water Resources}

The Glass Mountain KGRA is situated in the transition zone between the Cascade and Modoc geomorphic provinces. Most of the KGRA lies at the altitude above 6000-ft. The surface drainage pattern is poorly developed because the highly permeable volcanic rock allows the precipitation and 
snowmelt to infiltrate rapidly. The annual precipitation at the Gl ass Mountain KGRA is around $40-i n$. per year.

Five drainage basis overlay the Glass Mountain KGRA. These include: the Oklahoma, the Lava Beels, the Medicine Lake, the McArthur and the Big Valley drainage basins. There are no perennial streams in the general area of the Gl ass Mountain KGRA.

Surface Water Resources -- The most significant surface water resource is Medicine Lake. Clear Lake Reservoir, Tule Lake Sump and lower $\mathrm{Kl}$ amath Lake are located to the north of the KGRA.

Medicine Lake -- Medicine Lake is located within a small closed drainage basin having a surface area of $23 \mathrm{sq}$. mi. The surface area of the lake is 425 acres and the volume is 7,000 acre-ft. The lake occupies a volcanic crater.

Clear Lake Reservoir -- The storage capacity of Clear Lake Reservoir is estimated to be 527,000 acre-ft. The surface area is 24,800 acres. Clear Lake Reservoir is designated as a national wildifife refuge therefore the water is not available for any other purpose.

Groundwater -- Four groundwater basins are located in the vicinity of the Gl ass Mountain KGRA. The groundwater basins include Butte Valley, Bid Rock Valley, Tule Lake, and Lower $\mathrm{Kl}$ amath Lake. Butte Valley is by $\mathrm{far}$ the most significant of the four groundwater basins. Butte Valley is a closed basin located about 20 miles northwest of the KGRA, and has a surface area of $475 \mathrm{sq.} \mathrm{mi.(11)} \mathrm{Well} \mathrm{yields} \mathrm{in} \mathrm{excess} \mathrm{of} 4000 \mathrm{gpm}$ have been reported and the water quality TDS ranges from 100 to $1800 \mathrm{ppm}$.

The Tule Lake groundwater basin is part of the Klamath River Valley groundwater basin and is located approximately 10 miles to the north of the KGRA. Well yields in excess of $3000 \mathrm{gpm}$ have been reported. (11) 


\subsubsection{Competing Water Demands}

The Glass Mountain KGRA is located in ASA 1801. The CSS is estimated to be $3087 \mathrm{Mgd}$ and occurs during 0ctober. During 1975 the competing water consumptive use was estimated to be $1481 \mathrm{Mgd}$. The competing consumptive use is predicted to increase to $2415 \mathrm{Mgd}$ by the year 1990. Although the KGRA is located within an ASA that appears to have a sufficient supply of surface water for purposes of condenser cooling, in the immediate vicinity of the KGRA the surface water resources are extremely limited.

Development of geothermal power plants on US Forest Service 1 and will require coordination and approval by the agency. The position of the US Forest Service is important and should be addressed early in the planning process.

\subsection{NORTHEASTERN CALIFORNIA}

Northeastern California contains two KGRAs, Surprise Valley and Lassen. Surprise Valley is located in the northeastern corner of the state near the Oregon and Nevada borders. Lassen is located in Lassen National Forest.

\subsubsection{Surprise Valley KGRA}

The Surprise Valley KGRA is located in a remote part of northern California. The KGRA occupies an area covering 73,000 acres. The Department of Energy development plan calls for a total development of 2000 MWe. However, before 1990 less than 2500 MWe are planned to be developed. (4)

\subsubsection{Geothermal Resource Characteristics}

The Surprise Valley KGRA is classified as a low enthalpy liquid dominated resource. A large number of test wells have been drilled but no commercial 
development of the resource has taken place. Subsurface temperatures are in excess of $302^{\circ} \mathrm{F}\left(150^{\circ} \mathrm{C}\right) .{ }^{(4)}$ It is assumed the resource will be developed using the binary-type system. There is evidence of subsidence in the area, therefore it is assumed that development of the resource will require $100 \%$ recharge unless subsidence is not considered an important variable. Water requirements are estimated to be approximately 5000 gal per minute per 100 MWe.

\subsubsection{Water Resources}

The Surprise Valley KGRA is located east of the Warner Mountains in the North Lahontan Area of California. Elevation is $4500 \mathrm{ft}$ above sea level.

The general economy of the region is dependent upon agriculture, recreation, lumbering, and mining. The major agricultural activities are livestock production and growth of forage crops.

The total annual runoff generally exceeds present water cemands. Lack of stream flow regulation normally results in water shortages during portions of the irrigational season. Heavy snow packs are common during the winter months.

Surface Water Sources -- The nearest major surface water resources are located to the west of the Warner Mountains. Potential surface water resources within twenty miles of the Surprise Valley.KGRA include: Bidwell Creek, South Fork Pit River, North Fork Pit River, and Goose Lake.

Bidwel1 Creek -- Bidwe 11: Creek flows into the north end of Surprise Valley. Above Fort Bidwe 11, Bidwe 11 Creek drains an area of $25.6 \mathrm{sq} \mathrm{mi.} \mathrm{(12)} \mathrm{The}$ mean annual discharge of Bidwe 11. Creek measured at Fort Bidwell is $23 \mathrm{ft}^{3} / \mathrm{s}$. Runoff from the Bidwe 11 Creek drainage basin is calculated to

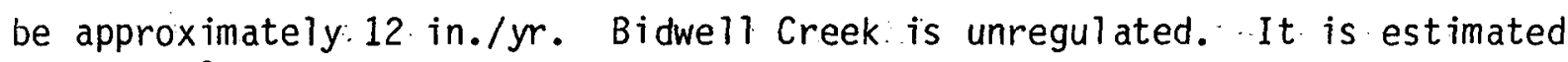
that $2 \mathrm{ft}^{3} / \mathrm{s}$ are diverted for irrigational usage. A minimum discharge of $1.4 \mathrm{ft}^{3} / \mathrm{s}$ was recorded on November $5,1960$. (12) 
South Fork Pit River -- The South Fork of the Pit River flows in a northerly direction paralleling the KGRA. The South Fork joins the North Fork near Alturas forming the Pit River. The Pit River flows west into the Sacramento River System. The average annual discharge for the South Fork of the Pit River near Likely, California is $80 \mathrm{ft}^{3} / \mathrm{s}$. Maximum and minimum record discharge are $1620 \mathrm{ft}^{3} / \mathrm{s}$ and $0.2 \mathrm{ft}^{3} / \mathrm{s}$. (12) The average annual runoff from the South Fork River Basin is approximately 4 in./yr. Mean monthly flow statistics for the South Fork Pit River are provided in Table 5.

Flow of the resource is partially regulated by West Valley Creek Reservoir. Diversion of water for irrigational usage is significant. A total of 4000 acres are irrigated from the mean annual discharge of 57,000 acre-ft/yr.

North Fork Pit River -- The North Fork Pit River parallels the KGRA, flowing in a generally southerly direction. The average annual discharge for the North Fork Pit River near Alturas, California is approximately $50 \mathrm{ft}^{3} / \mathrm{s}$. (12) The average annual runoff from the North Fork River Basin is approximately $4 \mathrm{in} / \mathrm{yr}$. Mean monthly flow statistics for the North Fork Pit River are provided in Table 6 .

Flow of the North Fork Pit River is partially regulated by Dorris Reservoir. Diversion for irrigational usage supports a total of 7000 acres.

Goose Lake -- Goose Lake is a large surface water resource located northwest of the KGRA. A major diversion effort would be required to use the resource for purposes of cooling.

Groundwater -- Groundwater exists in the mountainous regions of the Sacramento River Basin and the North Lahontan Subregion. Most usable water occurs in the valleys, which are filled with alluvium. Considerable groundwater exists in Surprise Valley. Total storage capacity within $400 \mathrm{ft}$ of ground surface is estimated to be 4,000,000 acre-ft. The range of total dissolved solids is $166-2,000$ ppm. Groundwater available in Goose Lake 
TABLE 5

MEAN MONTHLY FLOW OF SOUTH FORK PIT RIVER

(cubic feet per second)

$\begin{array}{lr}\text { Month } & \text { Flow } \\ \text { October } & 33 \\ \text { November } & 36 \\ \text { December } & 39 \\ \text { January } & 37 \\ \text { February } & 48 \\ \text { March } & 56 \\ \text { April } & 144 \\ \text { May } & 254 \\ \text { June } & 184 \\ \text { July } & 72 \\ \text { August } & 107 \\ \text { September } & 59\end{array}$


TABLE 6

MEAN MONTHLY FLOW OF. NORTH: FORK PIT RIVER

(cubic feet per second)

\begin{tabular}{lr}
\multicolumn{1}{c}{ Month } & Flow \\
\cline { 3 - 3 } October & 13 \\
November & 24 \\
December & 32 \\
January & 53 \\
February & 166 \\
March & 86 \\
April & 94 \\
May & 69 \\
June & 18 \\
July & 4 \\
August & 3 \\
September & 3
\end{tabular}


Valley is estimated to be 1,000,000 acre-ft, and in the Alturas.Basin the quantity of groundwater is estimated to be $6,700,000$ acre-ft. (8)

\subsubsection{Competing Water Demands}

The Surprise Valley KGRA is located in ASA 1802. The period of critical surface supply is September, and the flow is $9407 \mathrm{Mgd}$. The 1975 consumptive usage during September for ASA 1802 has been estimated to be 7132 Mgd representing over $75 \%$ of the CSS. Over 95 percent of the estimated 1975 consumptive use during the period of CSS was for the purpose of irrigation. The consumptive usage in ASA 1802 is predicted to remain rather constant through the year 2000. (13)

\subsubsection{Lassen KGRA}

The Lassen KGRA is located in Lassen National Forest. The DOE development scenario proposes a limited development of the resource prior to 1990 . A total development of 100 MWe prior to 1990 is forecast. Public opposition could limit development of the Lassen KGRA.

\subsubsection{Geothermal Resource Characteristics}

Test wells have been drilled on the Lassen KGRA. The resource is classified as a high enthalpy vapor and liquid-dominated resource. Subsurface temperature of the resource is estimated to be approximately $464^{\circ} \mathrm{F}\left(240^{\circ} \mathrm{C}\right)$. The resource could be developed using either the flash-steam process, or a binary type system. As indicated previously, public opposition may occur due to the aesthetics of the general area. Furthermore, there is some concern, which may or may not be valid, that development of the resource could place a drain on the geothermal characteristics within Lassen National Park. Water requirements are estimated to range from 0 to $4000 \mathrm{gal}$ per minute per 100 MWe, depending upon recharge requirements. 


\subsubsection{Water Resources}

The Lassen KGRA is located in a region that appears to be abundant with water resources. Average elevation of the site is over $6000 \mathrm{ft}$, restricting the existence of high volume surface water runoff resources. Small lakes are common.

Surface Water Resources -- Potential surface water sources are the North Fork Feather River, Butte Creek, and Lake Almanor. The North Fork Feather River has its headwaters in the vicinity of the Lassen KGRA. As far as is known, no gaging stations exist upstream of Lake Almanor (elevation 4510 $\mathrm{ft}$ ). Based upon discharge measurements from adjacent basins, the runoff is estimated at approximately $17 \mathrm{in./yr}$. The mean annual discharge of the North Fork Feather River at Chester, California (confluence of North Feather River and Lake Almandor) is estimated to be $100 \mathrm{ft}^{3} / \mathrm{s}$. Upstream regulation and diversion do not exist.

Butte Creek -- The Butte Creek drainage basin is located to the south of the North Fork Feather River Basin. Butte Creek flows into Butte Valley Reservoir (elevation $4163 \mathrm{ft}$ ). Average annual discharge of Butte Creek is $85 \mathrm{ft}^{3} / \mathrm{s}$. Mean Monthly Flow Statistics for Butte Creek are provided in Table 7. There is no regulation above Butte Valley Reservoir and diversion of flow is assumed negligible.

Lake Almanor -- Lake Almanor is a large reservoir, having a volume of approximately $1 \times 10^{6}$ acre-ft, located in the Upper Sacramento River Basin. Lake Almanor is in the Feather River drainage Basin. Water releases from reservoirs within the Feather River drainage basin serve multiple purposes. Use of Lake Almanor water would probably require considerable review. Lake Almanor is used by Pacific Gas and Electric Company for purposes of hydroelectric power generation. 
TABLE 7

MONTHLY FLOW STATISTICS FOR BUTTE CREEK

(cubic feet per second)

\begin{tabular}{lrr}
\multicolumn{1}{c}{ Month } & & Mean \\
October & & 64 \\
November & & 76 \\
December & & 85 \\
January & & 124 \\
February & & 154 \\
March & & 150 \\
April & & 230 \\
May & & 245 \\
June & & 118 \\
July & 63 \\
August & 61 \\
September & 60
\end{tabular}


Groundwater -- Groundwater exists in the alluvium filled Lake Almanor Valley. The surface area of the resource is estimated at seven sq mi. Total capacity above a depth of $210 \mathrm{ft}$ is estimated to be 45,000 acre- $\mathrm{ft}$. Maximum yield is estimated to be $300 \mathrm{gal}$ per minute. $(7,8)$

\subsubsection{Competing Water Demands}

The Lassen KGRA is located in ASA 1802. Refer to Section 3.2.1.3 for a discussion of competing uses. Development of the KGRA would require approval by the United States Forest Service.

\subsection{CENTRAL AND SOUTHERN CALIFORNIA}

Three major resource areas exist in central and southern California. The Mono-Long Valley KGRA is located in central California. The Coso KGRA is located in south central Caifornia, and in southern California the Imperial Valley hosts four KGRAs; Salton Sea, East Mesa, Brawley, and Heber.

\subsubsection{Mono-Long Valley KGRA}

The Mono Lake and Long Valley region is located directly east of San Francisco near the Nevada border. The Department of Energy development scenario postulates 250 MWe to be installed prior to $1990 .^{(4)}$

\subsubsection{Geothermal Resource Characteristics}

The Mono-Long Valley KGRA is classified as a high enthalpy liquid dominated resource. Over the years, extensive drilling and characterization of the resource have taken $\mathrm{place}$. Subsurface temperatures in excess of $428^{\circ} \mathrm{F}$ $\left(220^{\circ} \mathrm{C}\right)$ have been established. Depth to the reservoir averages $1000 \mathrm{ft}$, and the total dissolved solids is around $2000 \mathrm{ppm} .{ }^{(1,4)}$ The resource could be developed using either the flash-steam, or binary fluid processes. Some seismic noise and microearthquakes have been detected, but generally 
speaking a low level of seismic activity exists. The existence of sink holes does indicate the possibility of subsidence. Water resource requirements are estimated to range from 0 to 4000 gal per minute per 100 MWe. If reinjection is not required, the estimated water resource requirements are small. Additional research is required to better define the resource and power cycle to be used.

\subsubsection{Water Resources}

The Mono-Long Valley KGRA is located in the South Lahontan Water Resource region. Economic development was slow until 1960. Until recently, agriculture $\mathrm{placed}$ the greatest in-basin demand upon the available water resources in the northern section of the valley. Over the last 10 years, industrial development has steadily increased in the southern section of the South Lahontan Water Region. However, development of the surface water resources in the Mono Lake and Long Valley region has been extensive for many years. Water has been exported from the valley to the major municipalities of Los Angeles and San Diego since the late 1920's. At several locations in the Mono-Owens Valley, use of groundwater exceeds the annual recharge, resulting in a falling water table.

Surface Water Resources -- The most notable surface water resources existing in the Mono Lake and Long Valley Region include the Owens River, Crowley Lake, and Mono Lake. The mean annual natural runoff for the entire subregion is $1.2 \times 10^{6}$ acre-ft. The surface water resources of the region have been extensively developed by the municipalities of San Diego and Los Angeles. Exports to other subregions in California exceed 350,000 acre-ft. Re-allocation of Colorado River water resulting from the Central Arizona Project will require an additional export of water from the Mono-Long Valley subregion.

Owens River -- The Owens River has its headwaters in the Sierra Nevada Mountains. From its headwaters, the river flows east into Lake Crowley and then in a general southeasterly direction into the Tinemaha Reservoir. The Los Angeles aqueduct receives its water from the Tinemaha Reservoir. 
Gaging stations are infrequent along the Owens River. The runoff is estimated to average approximately 5 in: annually. Estimating the drainage basin area for the Owens River above Lake Crowley to be $4000 \mathrm{sq} \mathrm{mi}$, the mean annual discharge is calculated to be approximately $150 \mathrm{ft}^{3} / \mathrm{s}$.

As implied in the previous paragraphs, considerable demand is presently being placed upon the waters of the Owens River. The City of Los Angeles Department of Water and Power manages the Owens River Basin.

Lake Crowley -- Lake Crowley is located in Owens Valley. The Owens River flows both into and out of Lake Crowley. The resource is managed by the City of Los Angeles and is dedicated for use by the City of Los Angeles Department of Water and Power.

Mono Lake -- Mono Lake is located in the northwest corner of the KGRA. Topographically, Mono Lake lies within a closed drainage basin. Total area of the basin is approximately $740 \mathrm{sq} \mathrm{mi.} \mathrm{Playas} \mathrm{and} \mathrm{closed} \mathrm{drainage} \mathrm{basins}$ are common in the South Lahontan Subregion.

Mono Lake is part of the surface-water development in the South Lahontan Subregion operated by the City of Los Angeles. A tunnel with a capacity of $200 \mathrm{ft}^{3} / \mathrm{s}$ carries water from the Mono Lake Basin into the Owens River Basin.

Groundwater -- Most usable groundwater is located in scattered alluviumfilled valleys. The alluvium generally consists of semi-consolidated clay, silt, sand and gravel. Mountain areas are underlain by consolidated sedimentary, igneous, and metamorphic rocks. The consolidated rock formations contain only small quantities of recoverable groundwater.

Over 50 valley filled aquifers have been identified as significant sources of groundwater. The total storage capacity of the 50 basins is in excess of $134,000,000$ acre-ft. $(7,8)$ Two groundwater basins; Mono Valley and Owens Valley, appear most suitable for development of geothermal resources in 
the Mono Lake and Long Valley Region. However, although the groundwater resource appears to be somewhat large, the present rate of usage creates an overdraft. As a result, future development will be limited.

Mono Valley is underlaid with a water basin which occupies $246 \mathrm{sq} \mathrm{mi}$ of surface area. The total storage capacity is estimated to be $3.4 \times 10^{6}$ acre- $\mathrm{ft}$ between 20 and $200 \mathrm{ft}$ below ground surface. The range of dissolved solids is 60 to $2060 \mathrm{ppm}$. $(7,8)$

Similar to Mono Valley, Owens Valley is underlain with considerable groundwater. The surface area of the Owens' Valley groundwater resource is estimated to be $1031 \mathrm{sq} \mathrm{mi}$. Between the elevations of 20 to $220 \mathrm{ft}$, the usable storage capacity of the basin is estimated to be 12,000,000 acre $\mathrm{ft}$. Wells yielding over 3000 gal per minute have been located in the reservoir. The range of dissolved solids is 100 to $400 \mathrm{ppm} .(7,8)$

\subsubsection{Competing Water Demands}

The Mono-Long Valley KGRA is located in ASA 18n7. The month of the critical surface supply (CSS) is 0ctober. The CSS for ASA 1807 is $377.6 \mathrm{Mgd} .{ }^{(10)}$ The average export of water from the Mono-Long Valley subregion is $350 \mathrm{Mgd}$. In addition to export, the consumptive demand from irrigational usage ranges as high as 700 Mgd during the summer months. ${ }^{(13)}$ The demand for water in the Mono-Long Valley KGRA is great.

\subsubsection{Imperial Valley KGRA}

Four major KGRAs exist in the Imperial Valley; Salton Sea, East Mesa, Brawley, and Heber. Although the characteristics of the KGRAs are distinctly different, water resource utilization for the purpose of geothermal resources development is similar, and the subject will be discussed collectively in Section 3.3.2.2. 


\subsubsection{Geothermal Resource Characteristics}

Salton Sea -- The Salton Sea KGRA is classified as a high enthalpy liquid convective resource. The top of the reservoir is $3,281 \mathrm{ft}(1000 \mathrm{~m})$ below ground level. The U.S. Geological Survey reports that a number of holes have been drilled to a depth of $7,874 \mathrm{ft}(2400 \mathrm{~m})$ (1) Temperatures of the hypersaline brine, total dissolved solids of $250,000 \mathrm{ppm}$, is $680^{\circ} \mathrm{F}$. $\left(360^{\circ} \mathrm{C}.\right)$ Total area of the Salton Sea KGRA is 95,800 acres.

The Department of Energy development scenario postulates 600 iWe of capacity to be developed prior to 1990 . Total installed electrical energy potential is set at approximately 2000 MWe. ${ }^{(4)}$

The resource could be used to generate steam for electric power generation, or for desalination. Resource characteristics would suggest a secondary working fluid or binary process to be used for converting geothermal energy into electrical energy. The resource would be recharged directly. System makeup requirements are estimated to be 3500 gal per minute per 100 MWe.

Rex ${ }^{(14)}$ has estimated that brine reserves in the Imperial Valley may be sufficient to support 1000 to 3000 geothermal wells. Average yield per well is estimated to be 10.6 acre-ft of fresh water per day $\left(5.3 \mathrm{ft}^{3} / \mathrm{s}\right.$ or approximately 2500 gal per minute). Therefore, the freshwater yield from one geothermal well is nearly sufficient to support the cooling requirements for 100 MWe of installed capacity. The feasibility of a large scale geothermal operation/water management program should be reviewed.

East Mesa -- The East Mesa KGRA is classified as a high enthalpy liquid convective resource. ${ }^{(4)}$ The top of the reservoir is estimated to be $1000 \mathrm{~m}$ below ground leve1. Temperature of the resource is estimated at $358^{\circ} \mathrm{F}$ $\left(180^{\circ} \mathrm{C},\right)$ and the total dissolved solids is $500 \mathrm{ppm}$. (4) 
The East Mesa KGRA covers a region of 38,365 acres. The DOE development scenario postulates 100 MWe of installed capacity to be developed prior to 1990. Using a secondary or binary process, 100 percent return flow, water requirements are estimated at 4000 to $5000 \mathrm{gal}$ per minute per $100 \mathrm{MWe}$. An 11 MWe binary cycle demonstration plant is being constructed at East Mesa.

Brawley -- The Brawley KGRA is classified as a high enthalpy liquid convective resource. Subsurface fluid temperatures range from $446^{\circ} \mathrm{F}$ to $536^{\circ} \mathrm{F}$ $\left(230^{\circ} \mathrm{C}\right.$ to $\left.280^{\circ} \mathrm{C}\right) .{ }^{(4)}$ Total dissolved solids are $100,000 \mathrm{ppm}$. The postulated development scenario for Brawley KGRA proposes 500 MWe of installed capacity to be developed prior to 1990 . The resource is estimated to have a development capacity of 1000 MWe.

Similar to other KGRAs in the Imperial Valley, based upon subsidence considerations, it is assumed that a binary cycle will be used in developing the resource. The geothermal fluid withdrawn will be recharged. It is estimated that 3000 to 4000 gal per minute per 100 Mwe will be required for purposes of cooling.

Heber -- The Heber KGRA is classified as a high enthalpy liquid convective resource. Subsurface temperatures range from $320^{\circ} \mathrm{F}$ to $365^{\circ} \mathrm{F}\left(160^{\circ} \mathrm{C}\right.$ to $185^{\circ} \mathrm{C}$ ). Total dissolved solids are $14,000 \mathrm{ppm}$. The total surface area of the KGRA is 58,568 acres. (4)

The site has been under investigation for many years, and has been selected for study of the feasibility of low salinity hydrothermal conversion. The Heber KGRA has also been selected as one of the candidate sites for the geothermal demonstration $\mathrm{pl}$ ant. The development scenario for the Heber KGRA proposed 1000 MWe of capacity to be installed prior to 2020. 300 MWe of capacity will be installed prior to 1990 . 


\subsubsection{Water Resources}

The Imperial Valley is located in the Colorado Desert Subregion in the southeast corner of California. The dominate feature of the subregion from the standpoint of water supply is the Colorado River. The largest diversion of Colorado River water is made at Imperial Dam for irrigation, domestic, and industrial use in the Imperial Valley and Coachella Valley. The Imperial Irrigation District controls the surface water and waste drainage system in the Imperial Valley.

Surface Water Sources -- Surface water resources in the area include the Colorado River, the Salton Sea, the New River, and the Alamo River.

Colorado River -- The Colorado River provides drainage and water supply for large areas of seven western states. Over the years the Colorado River Basin has been extensively developed, principally at Hoover Dam, which was completed in 1935. Lake Mead, formed by the dam, can store a two-year flow for use in the Lower Colorado River Basin. The Lower Colorado River forms the boundary between California and Arizona.

Water is diverted from the Colorado River at Imperial Dam, approximately $40 \mathrm{mi}$ to the east of El Centro, California. The All-American Canal carries water from the Colorado River for use in the Imperial Valley. The mean annual flow rate in the All-American Canal at Imperial Dam is $6945 \mathrm{ft}^{3} / \mathrm{s}$. Statistical flow data for the All-American Canal at Imperial Dam are provided in Table 8 .

Diversion of Colorado River water for usage in California began at the turn of the twentieth century. The Alamo Canal was constructed to supply river water to both the Mexicali and Imperial Valleys. In 1911, the Imperial Irrigation district was formed. In 1928, the Boulder Canyon Project Act was passed to authorize construction of Hoover Dam and the All-American Canal system. The All-American Canal system includes the Imperial Dam, the All-American Canal and the Coachella Canal. 
TABLE 8

MEAN MONTHLY FLOW OF ALL-AMERICAN CANAL NEAR IMPERIAL DAM (cubic feet per second)

\begin{tabular}{lll}
\multicolumn{1}{c}{ Month } & Flow \\
October & & 5670 \\
November & & 4321 \\
December & & 3329 \\
January & & 4064 \\
February & & 5153 \\
March & & 8020 \\
April & & 8721 \\
May & & 7285 \\
June & & 8292 \\
July & 9585 \\
August & 9293 \\
September & 7445
\end{tabular}


Overuse of Colorado River water brought about litigation. A U.S. Supreme Court decision (Arizona vs. California) provided that California's annual apportionment from the Colorado River will be $4.4 \times 10^{6}$ acre-ft of the first $7.5 \times 10^{6}$ acre-ft, and fifty percent entitlement of all water in excess of $7.5 \times 10^{6}$. In the event of a shortage, the decree provides that the Secretary of the Interior apportion the available water. (15) Furthermore, the Colorado River Basin Project act of 1968 directs the Secretary to follow certain specific priorities in the event of a shortage. (16)

The Central Arizona Project is $\mathrm{pl}$ anned to become operational in the mid-1980's. Water for the Central Arizona Project will be diverted from the Colorado River near Lake Havasu, and conveyed by an open, concrete lined channel $182 \mathrm{mi}$ southeast to the service area. The long term average diversion of Colorado River water to support the Central Arizona Project is estimated to be 1.2 million acre-ft per year. When the project becomes operational, it is anticipated that the California appropriation of Colorado River water will be reduced to the 4.4 million acre-ft (minimum appropriation) or approximately $5427 \mathrm{ft}^{3} / \mathrm{s}$. As indicated previously, the annual flow rate of the $A 11$-American Canal has averaged $6945 \mathrm{ft}^{3} / \mathrm{s}$. Consequently, a reduction in the total available surface water beginning in the mid-1980's is anticipated. The primary use for water in the Imperial Valley is for agriculture.

The Al1 American Canal serves approximately 530,000 acres of 1 and in the Imperial Valley. Within the Imperial Valley, the All-American Canal feeds three main irrigation supply canals: the East Highline Canal, the Central Main Canal, and the West Side Main Canal. A network of smaller irrigation canals takes off from the three main canals traversing the area.

A system of drainage canals, consisting of tile drain interceptors, has been installed beneath most of the Valley. The drain tile system intercepts the percolating irrigation water below the ground surface and returns it to drainage canals. In the western part of the valley, drainage canals empty 
into the New River, while those in the east drain into the Alamo River. Agricultural wash water makes up the preponderance of surface water in both the $A 1$ amo and New River.

The tile drain intercept system was installed for the purpose of removing salt from the soil. Using the system, it is estimated that approximately $1 / 2$ million tons of salt are removed annually. Consequently, the water discharged to the New and Alamo Rivers has a rather high salt content, ranging from 2000 to $4000 \mathrm{ppm}$. Similarly, the salinity of water in the Salton Sea, which receives water from the New and Alamo Rivers, has been increasing.

New River -- The New River is formed in Mexico and flows north into the Salton Sea. There is very little physical relief throughout the entire drainage basin. The mean annual discharge of the New River is approximately $600 \mathrm{ft}^{3} / \mathrm{s}$. Nearly all water in the New River is derived from irrigational runoff. Mean monthly flow statistics for the New River are provided in Table 9 .

Alamo River -- The Alamo River is formed from irrigational runoff in the Imperial Valley. The mean annual discharge of the Alamo River is approximately $950 \mathrm{ft}^{3} / \mathrm{s}$, and is derived almost exclusively from irrigational runoff. Mean monthly flow statistics for the Alamo River are provided in Table 10.

Salton Sea -- The Salton sea is a saline body of water, occupying a natural site $30 \mathrm{mi}$ long and from 10 to $15 \mathrm{mi}$ wide with an average depth of $30 \mathrm{ft}$. The Salton Sea receives drainage from approximtely $7500 \mathrm{sq} \mathrm{mi}$ of surrounding watershed. Inflow results from agricultural runoff. The concentration level of the lake is slowly increasing. The concentration of dissolved solids is slightly higher than normal sea water.

Groundwater -- Most usable groundwater in the Colorado Desert Subregion occurs in alluvium-filled valleys. Within the vicinity of the Imperial KGRA, the Imperial Valley groundwater basin appears most suitable for 


\section{TABLE 9}

FLOW STATISTICS FOR THE NEW RIVER (cubic feet per second)

\begin{tabular}{lll}
\multicolumn{1}{c}{ Month } & & Mean \\
October & & 644 \\
November & & 545 \\
December & & 525 \\
January & & 551 \\
February & & 586 \\
March & & 656 \\
Apri1 & & 686 \\
May & & 615 \\
June & & 564 \\
July & & 559 \\
August & & 578 \\
September & & 593
\end{tabular}


TABLE 10

MONTHLY FLOW STATISTICS FOR THE ALAMO RIVER

(cubic feet per second)

\begin{tabular}{lrr}
\multicolumn{1}{c}{ Month } & Mean \\
October & & 1046 \\
November & 797 \\
December & 633 \\
January & 733 \\
February & 830 \\
March & 1015 \\
April & 1073 \\
May & 941 \\
June & 832 \\
July & 800 \\
August & 838 \\
September & 940
\end{tabular}


supplying cooling water. Surface area of the resource is approximately 1900 sq mi. The storage capacity between elevations $100 \mathrm{ft}$ and $300 \mathrm{ft}$ below ground level is estimated to be $14.7 \times 10^{6}$ acre-ft. $(7,8)$ Total dissolved solids content ranges from 700 to $3600 \mathrm{ppm} .(7,8)$ Properly constructed wells can yield 4000 gallons per minute.

Safe groundwater yield for the entire Colorado Desert Subregion is estimated to be 100,000 acre-ft per year. An overdraft of 200,000 acre-ft currently exists in the Colorado Desert Subregion. A further review of existing groundwater resources and availability of groundwater in storage is recommended.

\subsubsection{Competing Water Demand}

The Imperial Valley KGRAs are located in ASA 1806. The critical surface supply is 2961 Mgd during October. (10) The 1975 consumptive water demand was estimated to be $3940 \mathrm{Mgd}$. (13) The primary use for water is agricultural irrigation (1861 Mgd). Agricultural usage is projected to decrease during the 1980's and 1990's. However, the total supply will also be reduced as a result of the Central Arizona Project. The consumptive demand resulting from domestic usage will increase during the 1980's and 1990's. Domestic usage is predicted to increase from $700 \mathrm{Mgd}$ to $1000 \mathrm{Mgd}$ by the year 2000 .

Use of surface water from the Imperial Irrigation District for the purpose of developing geothermal Energy resources has been obtained, but is limited to 75 MWe. An agreement for 5000 acre-ft of water for five years has been finalized between IID and San Diego Gas and Electric and is being used at the Heber KGRA. (11)

\subsubsection{COSO KGRA}

The Coso KGRA is located approximately 100 miles northwest of Los Angeles, at the southern end of the Owens Valley. The Department of Energy Department Scenario postulates 600 MWe of installed capacity prior to 1990 . 


\subsubsection{Geothermal Resource Characteristics}

The mean resevoir temperature of the Coso geothermal resource is estimated to be $446^{\circ} \mathrm{F}\left(230^{\circ} \mathrm{C}\right)$. (1) The resource is classified as a high enthalpy convective resource. It is assumed the resource will be developed using a flash steam expansion process, and the recovered condensate will be used for purpose of cooling tower makeup. The water quality of the geothermal resources will be an important consideration in developing the Coso KGRA. It is estimated that development of the resource will require between 0 to 4500 gal per minute per 100 MWe.

\subsubsection{Water Resources}

The availability and assumed use of outside sources of makeup water for power $\mathrm{plant}$ operation is a major consideration in developing geothermal resources in the COSO KGRA.

Surface Water Resources -- The average annual precipitation in the vicinity of the Coso KGRA is less than $10 \mathrm{in.}$. The Los Angeles Aqueduct and the Hainee Reservoir are the only significant surface water resources. Both resources are owned and controlled by the Los Angeles Department of Water and Power. The Hainee Reservoir has a storage capacity of 510,000 acre-ft. Flow in the Los Angeles Aqueduct exceeds 300,000 acre-ft per year. Owens Lake (dry), which is located north of the KGRA, sometimes receives overflow from the Los Angeles Aqueduct. The overflow is waste and typically amounts to 2000 acre- $\mathrm{ft}$ year. (8)

Groundwater -- The groundwater table in the general vicinity of the coso KGRA is falling. An estimate of the groundwater stored in the area is approximately 1.9 million acre-ft with a TDS of less than $1000 \mathrm{ppm}$ and 2.1 million acre-ft with a TDS of less than $4000 \mathrm{ppm}$. The only major source of groundwater recharge is seepage from the Haiwee Reservoir. Recharge from the Haiwee Reservoir is estimated to be 11,000 acre-ft per year. Current pumpage rates exceed 15,000 acre-ft per year. 


\subsubsection{Competing Water Demands}

The Coso KGRA is located in ASA 1807. Competing Water Demands in ASA 1807 are discussed in Section 3.3.1.3. In the immediate vicinity of the KGRA, completion for water (ground) exists from the community of China Lake, and the nearby Naval Weapons Station. 
4.0 WATER RESOURCES FOR DEVELOPMENT OF GEOTHERMAL SITES IN ARIZONA

Two KGRAs exist in Arizona: the Chandler KGRA, located approximately $20 \mathrm{mi}$ Southeast of Phoenix, and Safford KGRA, located approximately $120 \mathrm{mi}$ east of Phoenix in the Gila Mountains.

\subsection{CHANDLER KGRA}

Development of the Chandler KGRA has been slow. Total surface area and development potentials of the resource are unknown. The Department of Energy development scenario postulates 150 MWe of installed capacity prior to 1990 .

\subsubsection{Geothermal Resource Characteristics}

Prior to 1975 two deep wells $(3 \mathrm{~km})$ had been drilled into the Chandler KGRA. Bottom-hole temperatures of $325^{\circ} \mathrm{F}$ to $363^{\circ} \mathrm{F}\left(163^{\circ} \mathrm{C}\right.$ and $\left.184^{\circ} \mathrm{C}\right)$ were recorded. The resource is classified as a high enthalpy convective resource. It is assumed that development of the resource would require use of a binary type cycle with complete recharge of the resource or a substitute resource. Mining of groundwater in the vicinity of Phoenix has resulted in subsidence. To prevent further subsidence, recharge practices will undoubtedly be encouraged. It is estimated that development of the resource will require 3500 to 4500 gal per minute per 100 MWe.

\subsubsection{Water Resources}

The development of any new water consuming industry in Arizona will encounter strong opposition. The availability of water in central Arizona is extremely limited.

For years, the development of geothermal resources in Arizona has been looked upon as a means of augmenting the available water resource. It is estimated that ..." a potential for up to 6 million acre-ft of distilled 
water per year and electrical output 15 times greater than that of Hoover Dam"... (17) can be developed from geothermal resources in Arizona. Consequently, it would seem that $\mathrm{plans}$ for developing the geothermal potential in and around Phoenix must incoporate a dual purpose capability; electrical energy production and desalination.

Surface Water Resources -- The primary surface water resources in the vicinity of the Chandler KGRA are the Salt and Gila Rivers. Development of both resources is extensive.

Salt River -- The Salt River is located in the north of the KGRA. The Salt River is a major tributary of the Gila River draining the north central portion of the Gila drainage basin. The Salt River basin above Phoenix is one of the few regions in south central Arizona where groundwater pumpage is not relied upon to meet growing demands. However, stream flow in the Salt River in the Phoenix area is only on an intermittent basis. Between 1941 and 1965 there was no flow in the Salt River in the Phoenix area.

Gila River -- The water supply from the Gila River has been developed and fully utilized for decades. (17) Except for infrequent 1 arge floods and periods of exceptional runoff, the flow rate of the Gila River south of Phoenix is nonexistent. Furthermore, there is flow in the Gila River downstream of Coolidge Dam, $80 \mathrm{mi}$ east of Phoenix, only on an irregular basis.

Groundwater -- Generally speaking, groundwater overdrafts have sustained the development of the Gila River Basin for several decades. In 1970 the annual withdrawal of groundwater was estimated to be approximately 5 million acre-ft. This rate of withdrawal represents an overdraft of approximately 3 million acre-ft. Safe yield of approximately 2 million acre-ft was exceeded in the early 1940's, and as a result the water table has been dropping steadily. The Central Arizona Project is directed towards stabilizing or reducing the rapid decline of the groundwater level. 


\subsubsection{Competing Water Demands}

The Chandler KGRA is located in ASA 1503. The critical surface supply, which occurs in July, is $3273 \mathrm{Mgd}$. The coincident irrigation demand alone in 1975 was approximately $6000 \mathrm{Mgd}$. The total consumptive demand in 1975 was $6500 \mathrm{Mgd}$. The irrigation demand is expected to decrease. The total consumptive demand is predicted to be $4500 \mathrm{Mgd}$ in the year 2000 .

\section{$4.2 \quad$ SAFFORD KRGA}

Similar to the Chandler KGRA, development of the Safford KGRA has been slow. The resource is situated in the Gila Mountains to the east of Phoenix. Mineral exploration holes drilled to the depth of $1000 \mathrm{ft}$ have encountered temperatures in excess of $212^{\circ} \mathrm{F}\left(100^{\circ} \mathrm{C}.\right)$ Subsurface temperatures in excess of $392^{\circ} \mathrm{F}\left(200^{\circ} \mathrm{C}\right)$ are estimated. The size and characteristics of the resource are not well defined. The DOE development scenario postulates 50 MWe of installed capacity prior to 1990. Assuming a binary process with complete return of the geothermal resource to be employed for purposes of development, water usage is estimated to be $2500 \mathrm{gal}$ per minute per 50 MWe.

As indicated in previous sections, the water resources of central Arizona have been depleted for many years. The Safford KGRA is located near the headwaters of the Salt River. Surface water does exist, but its use could be entirely accounted for based upon the extensive demonstrated demand. The availability of water, both surface water and groundwater, for developing the Safford KGRA is unknown.

The Safford KGRA is located in ASA 1501. The CSS is $287 \mathrm{Mgd}$. The $1975 \mathrm{con}-$ sumptive demand was estimated to be 160 Mgd. Exportation requirements of the Gila River are unknown but assumed to account for the balance, since the flow in the Gila River in the vicinity of Phoenix is nonexistent. 
48 
In Utah, three geothermal resources will be discussed. They include the Thermo KGRA, the Roosevelt Hot Springs KGRA, and the Cove Fort-Sulphurdale KGRA. All three resources are located in the Sevier Lake Drainage Basin in the southwest corner of the state. The three sites are located within a few dozen miles of one another.

\subsection{THERMO KGRA}

Development of the Thermo KGRA is anticipated to occur primarily during the 1990 's. The development scenario postulated by DOE proposes that 50 MWe of capacity will be installed prior to 1990. The estimated surface area of the KGRA is approximately 26,000 acres. The electrical energy potential of the resource is set at 500 MWe. (4)

\subsubsection{Geothermal Resource Characteristics}

A number of surface springs exist at the Thermo KGRA. The Thermo site is the smallest of the three KGRAs in Utah that will be discussed. The total heat content of the resource as estimated by the U.S. Geological Survey is $2.8 \times 10^{18}$ calories. (1) Subsurface temperatures are estimated to be in excess of $284^{\circ} \mathrm{F}\left(140^{\circ} \mathrm{C}\right.$.) The resource is classified as a low enthalpy convective resource.

It is assumed that the resource will be developed using either the flash steam expansion process, or the binary secondary working fluid process. Therefore, water resource requirements are estimated to range from 0 to 5500 gal per min/100 MWe.

\subsubsection{Water Resource}

Water resources are discussed in Section 5.4 . 


\subsection{ROOSEVELT HOT SPRING KGRA}

Development of the Roosevelt Hot Springs KGRA is postulated to begin in the early 1980's. The installed capacity in 1990 is estimated to be 250 MWe. Total surface area of the KGRA is approximately 30,000 acres. The electrical energy potential is estimated to be 1000 MWe.

\subsubsection{Geothermal Resource Characteristics}

From 1908 to 1957 the temperature of surface hot springs decreased from $190^{\circ} \mathrm{F}$ to $131^{\circ} \mathrm{F}\left(88^{\circ} \mathrm{C}\right.$ to $\left.55^{\circ} \mathrm{C}\right) .{ }^{(1)}$ The springs have become sealed with silicon oxide and have ceased discharging. (4) A number of test wells have been drilled into the KGRA and the characteristics are fairly well defined. Subsurface temperature of the resource ranges from $399^{\circ} \mathrm{F}$ to $500^{\circ} \mathrm{F}\left(204^{\circ} \mathrm{C}\right.$ to $\left.260^{\circ} \mathrm{C}\right)$. The resource is defined as a high enthalpy convective resource. Total dissolved solids are $7800 \mathrm{ppm}$, and depth to the top of the resource is $2,723 \mathrm{ft}$ ( 830 meters).

The resource could be developed using either the flash stream process or the binary working fluid process. Water resource requirements are estimated to $r$ ange from zero to 4500 gal per minute/100 MWe.

\subsubsection{Water Resources}

To be discussed in Section 5.4 .

\subsection{COVE FORT-SULPHURDALE KGRA}

Development of the Cove Fort-Sulphurdale KGRA is not scheduled to begin until the mid 1980's. The first installed capacity of 50 MWe is scheduled for 1985. A total of 200 MWe installed capacity is postulated prior to 1990. The Cove Fort-Sulphurdale KGRA is estimated to be largest in Utah, with a total potential of 1500 MWe. 


\subsubsection{Geothermal Resource Characteristics}

The U.S. Geological Survey estimates the heat content of the resource to be $16.0 \times 10^{18}$ calories. The temperature of the resource is estimated to be $338^{\circ} \mathrm{F}\left(170^{\circ} \mathrm{C}\right)$. There are no surface springs, but active gas seeps exist, indicating the possibility of a vapor dominated regime. ${ }^{(1)}$ Further exploration is required to define the resource. Water development requirements are assumed to be similar to the other two KGRAs in the same geographic region ranging from 0 to $4500 \mathrm{gal}$ per minute per 100 MWe.

\subsubsection{Water Resources}

To be discussed in Section 5.4 .

\subsection{WATER RESOURCES}

Thermo, Roosevelt Hot Springs, and Cove. Fort-Sulphurdale KGRAs are located in the Sevier Subregion of the Great Basin. The geothermal sites are located near the Mineral Mountains in the southwest corner of the drainage basin. The region is characterized by playas and closed drainage basins. In the vicinity of the Thermo, and Roosevelt Hot Springs KGRAs the principal surface water sources appear to be the tributaries that flow into Rockyford Reservoir. In the vicinity of the Cove Fort-Sulphurdale KGRA, the principal surface water resource is Clear Creek. Clear Creek flows into the Sevier River approximately $20 \mathrm{mi}$ east of the site near Sevier, Utah.

\subsubsection{Surface Water Resources (Thermo and Roosevelt)}

The Thermo and Roosevelt KGRAs are located in a closed drainage basin. The major surface water resources are the Beaver River and Rockyford Reservoir. Virtually all of the surface water in the basin has been appropriated. (18)

Beaver River -- The Beaver River drains an area of $272 \mathrm{sq} \mathrm{mi}$. The river flows into Rockyford Reservoir near Adamsville, Utah. The mean annual 
average discharge of the resource is $35.5 \mathrm{ft}^{3} / \mathrm{s} .(19)$ Water in the Beaver River is used primarily for purposes of irrigation. The resource provides water for domestic usage at Adamsville, Utah and Beaver, Utah.

Rockyford Reservoir -- Rockyf ord Reservoir receives water from a drainage basin encompassing $510 \mathrm{sq} \mathrm{mi}$. The reservoir was formed with the construction of an earth filled dam in 1914. Total storage of the reservoir is less than 25,000 acre-ft. Water in the reservoir is used primarily for irrigation. (19)

\subsubsection{Surface Water Resources (Cove Fort-Sulphurdale)}

Clear Creek is the primary surface water resource near the Cove FortSulphurdale KGRA. The resource drainage basin is $164 \mathrm{sq} \mathrm{mi.} \mathrm{Mean} \mathrm{annual}$ discharge of the resource is $24 \mathrm{ft}^{3} / \mathrm{s}$. Water derived from Clear creek is used primarily for crop irrigation. Clear Creek flows into the Sevier River upstream of the Puite canal diversion. The annual diversion for Puite Canal is .65 million acre-ft. All water in the Sevier River has been appropriated.

\subsubsection{Groundwater Resources}

The groundwater resources existing in Utah are extensive. The underground reservoirs generally are much 1 arger than most surface water resources and hold 1 arge volumes of water. The Utah KGRAs are located in a region under1 ayered by the Milford-Beryl-Enterprise groundwater basin. The basin is estimated to contain enough water to fill Lake Mead. (20) Unfortunately, the groundwater resources existing in the Sevier River Basin have been developed to near their maximum potential. In 1977, total groundwater withdrawal from the Milford-Beryl-Enterprise groundwater basin was over 130,000 acre-ft. Safe yield is estimated to be 200,000 acre-ft annually. (20) The primary use of the water is for crop irrigation. (20) 


\subsubsection{Competing Water Demands}

All three KGRAs, Rooseve1t Hot Springs, Thermo, and Cove Fort-Sulphurdale are located in ASA 1602. The critical surface supply for the subarea is estimated to be $3861 \mathrm{Mgd}$. The 1975 total consumptive use requirements were estimated to be $1991 \mathrm{Mgd}$, suggesting the availability of water for development. However, it must be recognized that the water law in Utah is governed by the appropriate rights doctrine and that in the Sevier River drainage basin nearly all water has been appropriated.

Energy development will require that water be transferred from existing usage. For example, the Intermountain Power Project has proposed the construction of a four unit 3000 HWe coal fired $\mathrm{plant}$ in the Sevier River Basin. Water rights were purchased from existing agricultural usage at a price of $\$ 1750$ per acre-ft. The price represents an amount approximately an order of magnitude greater than the most optimistic estimate of its value for agricultural usage. (18) 
-

54

0

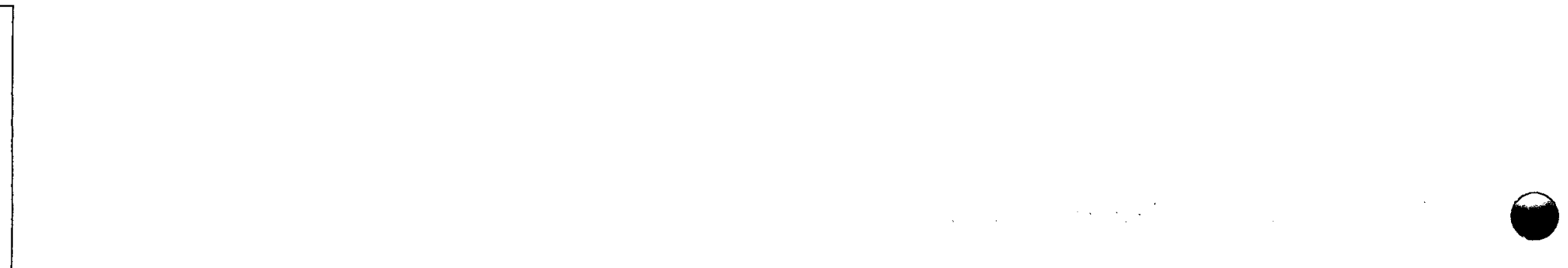


6.0 WATER RESOURCES FOR DEVELOPMENT OF GEOTHERMAL SITES IN NEVADA

The State of Nevada hosts four KGRAs. The four resources include:

Steamboat Springs KGRA near Reno, Brady Hot Springs KGRA, located approximately $40 \mathrm{mi}$ northeast of Reno, the Leach KGRA located approximately $30 \mathrm{mi}$ south of Winnemucca, and the Beowawe KGRA located approximately $40 \mathrm{mi}$ southwest of Elko.

\subsection{STEAMBOAT SPRINGS KGRA}

The development scenario postulated by the Department of Energy proposed that 100 MWe of capacity be developed prior to $1990 .^{(14)}$ Total development capacity is presently estimated to be 200 MWe.

\subsubsection{Geothermal Resource Characteristics}

A number of shallow wells have been drilled into the KGRA; these provide energy for space heating in the Reno suburbs. The resource has undergone extensive exploration and is well defined. Surface area of the Steamboat Springs KGRA is estimated to be approximately 9000 acres. The subsurface temperature of the resource is set at $410^{\circ} \mathrm{F}\left(210^{\circ} \mathrm{C}\right.$, ) and the total dissolved solid content of the resource is $2500 \mathrm{ppm}$. Depth of the top of the resource is $984 \mathrm{ft}(300 \mathrm{~m}) .{ }^{(4)}$ The resource is defined as a high enthalpy convective resource.

The resource could be developed using either the flash steam process or the binary working fluid process. Water requirements are estimated to range from 0 to 4500 gal per minute per 100 MWe.

\subsubsection{Water Resources}

The Steamboat Springs KGRA is located in the Central Lahontan Subregion. The subregion is characterized by closed river basins. Most surface water sources in the subregion have their headwaters in California, and as a result considerable upstream depletion exists. 
Surface Water Resources -- Potential surface resources that could be used for developing the geothermal resource include the Truckee River and Washoe Lake.

Truckee River -- Headwaters of the Truckee River are in the Sierra Nevada Mountains in eastern California. The drainage upstream area at the California-Nevada State line is $950 \mathrm{sq} \mathrm{mi}$. The mean annual discharge at Farad, California is approximately $780 \mathrm{ft}^{3} / \mathrm{s} .(25)$ Flow in the Truckee River is substantially regulated upstream of the state line.

The mean annual discharge of the Truckee River at Reno, Nevada is 650 $\mathrm{ft}^{3} / \mathrm{s}$. Many diversions exist downstream of Reno. Water from the Truckee River is used for irrigation, municipal, industrial, and recreational purposes. Much of the Truckee River flow is diverted to the Lahontan Reservoir, which supplies water for irrigation and wildlife usage.

Washoe Lake -- Washoe Lake is situated at the bottom of a closed basin. Total drainage area of the basin is $84 \mathrm{sq} \mathrm{mi}$. Storage within the lake is controlled. Volume of the reservoir is unknown.

Groundwater Resource -- Most of the valleys in the Central Lahontan Subregion contain fresh groundwater. In the vicinity of Steamboat Springs, however, the existence of groundwater is limited. Generally speaking, the groundwater resource of the subregion has been highly developed.

\subsubsection{Competing Water Demands}

The Steamboat Springs KGRA is located in the Central Lahontan Aggregated Subregion (1604). The critical surface supply is estimated to be $1879 \mathrm{Mgd}$. Total water consumptive demands in 1975 were estimated to be $1967 \mathrm{Mgd}$, or essentially 100 percent of the CSS. The primary use for water is agriculture. The overall pattern for water usage (supply vs demand) is not anticipated to change significantly between now and the year 2000. (13) 


\subsection{BRADY HOT SPRINGS KGRA}

The development scenarios postulated by the Department of Energy proposed that 300 MWe of electrial energy capacity be developed prior to 1990 . The total development of the resource is set at 1000 MWe.

\subsubsection{Geothermal Resource Characteristics}

The characteristics of the Brady Hot Springs KGRA are reasonably we 11 defined. Total surface area of the resource is estimated to be approximately 100,000 acres. The average subsurface temperature of the resource is estimated to be $311^{\circ} \mathrm{F}\left(155^{\circ} \mathrm{C}\right)$ and the total dissolved solids is 2450 ppm. Depth to the top of the reservoir is $1,640 \mathrm{ft}$ (500 meters).

Like the Steamboat Springs KGRA, the Brady Hot Springs resource is categorized as a low enthalpy convective resource. The resource could be developed using either the $\mathrm{fl}$ ash steam process or the binary working fluid process. Water requirements are estimated to range from 0 to 5500 gal per minute per 100 MWe.

\subsubsection{Water Resources}

The Brady Hot Springs KGRA is located in the Central Lahontan Subregion. Surface water resources are extremely limited. Hiumboldt Lake and Toulan Lake, located twenty to thirty miles northeast of the resource, are the nearest surface water resources.

Surface Water Resources -- Humboldt Lake and Toulan Lake form the sink for the Humboldt River. Flow of the Humboldt River below Rye Patch, Nevada is completely regulated by Rye Patch Reservoir and is $200 \mathrm{ft}^{3} / \mathrm{s}$. Characteristics of Humboldt Lake and Toulan Lake are unknown.

Groundwater -- The availability of groundwater in the vicinity of the Brady Hot Springs KGRA is unknown. The area is surrounded by several sinks and 
alkali flats, which are known not to contain groundwater. However, groundwater is known to exist in the Winnemucca Lake (dry) region northwest of the site.

\subsubsection{Competing Water Demands (Refer to Section 6.1.3)}

\section{$6.3 \quad$ LEACH KGRA}

The development scenario postulated by the Department of Energy proposes that less than 100 MWe of electrical energy capacity be developed prior to 1990. Site potential is estimated to be 1500 MWe.

\subsubsection{Geothermal Resources Characteristics}

Characteristics of the Leach KGRA are unknown. Subsurface resource temperatures are estimated to average $338^{\circ} \mathrm{F}\left(170^{\circ} \mathrm{C}\right)$. The resource is classified as a high enthalpy convective resource. It is assumed that the resource will be developed using a binary cycle. Water resource requirements are estimated to range as high as 5000 gal per minute per 100 MWe.

\subsubsection{Water Resources}

Both surface and groundwater resources are almost non-existent. Some groundwater may be available in the eastern portion of the KGRA, due to groundwater recharge below Reese River.

\subsubsection{Competing Water Demands}

The Leach KGRA is located in ASA 1603. The critical surface supply is estimated to be $4328 \mathrm{Mgd}$. (13) The integrated consumptive usage is 1975 for ASA 1603 was estimated to be $3738 \mathrm{Mgd}$. The integrated consumptive usage is predicted to be $4252 \mathrm{Mgd}$ in the year 2000. The principal use of water is irrigation. The usage pattern is not expected to change significantly between now and the year 2000. 
6.4 BEOWAWE KGRA

The development scenario postulated by the Department of Energy indicates 250 MWe of installed capacity prior to 1990. Site potential is set at 1000 MWe. Surface area of the Beowawe KGRA is approximately 33,000 acres.

\subsubsection{Geothermal Resource Characteristics}

Over the years the geothermal resource at Beowawe has been well characterized. Subsurface fluid temperatures range from $329^{\circ} \mathrm{F}$ to $536^{\circ} \mathrm{F}\left(165^{\circ} \mathrm{C}\right.$ to $280^{\circ} \mathrm{C}$ ). Average subsurface temperatures of the resource are estimated to be $464^{\circ} \mathrm{F}\left(240^{\circ} \mathrm{C}\right)$. Depth to the top of the reservoir is $3,281 \mathrm{ft}$ $(1000 \mathrm{~m})$ and the total dissolved solid content is $1200 \mathrm{ppm}$. The resource is classified as a high-energy liquid dominated system.

The resource could be developed using either the flash steam system or the binary cycle system. Water resource requirements are estimated to range from 0 to 4500 gal per minute/100 MWe.

\subsubsection{Water Resources}

The Beowawe KGRA is situated in the Humboldt River Subregion of the Great Basin. The Humboldt River is the principal stream of the subregion draining approximately 57 percent of the area. Total population of the subregion is estimated to be less than 30,000. Irrigation and recreation are the primary uses of water in the subregion.

Surface Water -- The primary surface water resource in the vicinity of the Beowawe KGRA is the Humboldt River.

Humboldt River -- The average annual discharge of the Humboldt River at Palisade, Nevada is $357 \mathrm{ft}^{3} / \mathrm{s}$. The Humboldt River is used extensively for irrigation and agricultural purposes. Depletion upstream of the Palisade gaging station amounts to more than 50 percent of the runoff between 
Palisade and Rye Patch Reservoir. The mean annual discharge at Imlay, Nevada (Rye Patch Reservoir) is $174 \mathrm{ft}^{3} / \mathrm{s}$.

Groundwater -- Groundwater is found in the alluvial deposits in most valleys of the Great Basin. In the Humboldt subregion, it is estimated that $45 \times 10^{6}$ acre- $\mathrm{ft}$ of groundwater is stored in the upper $100 \mathrm{ft}$ of the saturated deposits. The groundwater resource of the Humboldt River Subbasin has not been as extensively developed as those of other subbasins of the Great Basin. Present withdrawals are estimated to total less than 200,000 acre-ft annual1y. (20)

\subsubsection{Competing Water Demands}

The Beowawe KGRA is located in ASA 1603. Refer to Section 6.3.3 for a discussion of competing uses. 
A number of hot springs and potential geothermal resource areas exist in New Mexico. The most active geothermal area is the Valles Caldera KGRA, approximately $50 \mathrm{mi}$ north of Alburquerque, and $24 \mathrm{mi}$ west of Santa Fe.

\section{$7.1 \quad$ VALLES CALDERA KGRA}

The Department of Energy development scenario postulates 350 MWe of installed capacity to be developed from the Valles Caldera KGRA prior to 1990. The first unit, 50 MWe installed capacity, is scheduled to be on 1 ine in 1983. Public Service Co. of New Mexico plans to build the first unit at Valles Caldera as a joint venture with Department of Energy. A flash steam process will be used to convert the geothermal resource into steam electric power.

\subsubsection{Geothermal Resource Characteristics}

The characteristics of the Valles Caldera KGRA are well defined. Surface area of the resource is estimated to be approximately 170,000 acres. Subsurface resource temperatures range up to $600^{\circ} \mathrm{F}\left(316^{\circ} \mathrm{C}\right)$. Depth to the top of the reservoir is $1000 \mathrm{~m}$ and the total dissolved solids content is 6000 ppm. $(1,4)$

Potential development capacity of the Valles Caldera KGRA is set at approximately 1500 MWe. The resource is classified as a high enthalpy liquid dominated convective resource. The resource could be developed using either a flash steam process or binary cycle. Development of the resource using a $\mathrm{fl}$ ash steam process could result in sufficient recovery of the condensate to satisfy all requirements for wet evaporative cooling. Water resource requirements are estimated to range from 0 to $4000 \mathrm{gal}$ per minute per 100 MWe.

Development of a 50 MWe demonstration plant is presently planned. (21) A flash steam process will be used for the 50 MWe plant. 


\subsubsection{Water Resources}

Both surface and groundwater resources in New Mexico have been extensively developed. The principal surface water resource in the vicinity of the Valles Caldera KGRA is the Rio Grande River. Water of the Rio Grande River was adjudicated in the early 1890's. Since the early 1900's, the groundwater resources have received increasing pressure. It is generally believed that most of the economically usable groundwater in New Mexico has been located and developed. New Mexico has large quantities of brackish water in underground storage. It has been concluded that development of the vast coal resources in the San Juan Basin could proceed using brackish water. Bedrock aquifers containing brackish or high TDS water have been identified for the development of coal in the San Juan Basin. (22) It is assumed the development of geothermal energy will require the use of brackish water.

An application permitting the withdrawal of 35 acres ( $14 \mathrm{ha}$ ) of irrigated crop land from irrigation by Jemez River Water has been filled. A total of 44 acre-ft of irrigation water has been applied for to date. ${ }^{(21)}$ The proposed 50-Mle plant will be responsible for the retirement of an estimated 17.7 acre-ft of water. ${ }^{(21)}$ An additional 100-MWe of capacity is planned.

\subsubsection{Competing Water Demands}

The Valles Caldera KGRA is located in ASA 1302. The critical surface supply is estimated to be $670 \mathrm{Mgd}$. The total consumptive demand in 1975 was $848 \mathrm{Mgd}$. The critical period is 0ctober. The largest use of water is for agricultural purposes. In 1975, agriculture consumed over $700 \mathrm{Mgd}$ during the critical period. 
Considerable geothermal activity exists in and around the vicinity of West Yellowstone, Montana. A region outlined for exploration consists of a twomile wide buffer strip between Island Park, Idaho and the Yellowstone National Park boundary along the Idaho-Wyoming border. Although numerous thermal phenomena (thermal springs, geysers, etc.) have been observed, the existence of a suitable geothermal reservoir has not been established. Numerous shallow observation wells have been drilled. Temperatures of the resource have been estimated in excess of $626^{\circ} \mathrm{F}\left(330^{\circ} \mathrm{C}\right)$. "About 50 firms, including four major oil companies and an electrical co-op have applied for leases on 300,000 acres of the 500,000 acre district,..." (23)

Water resource requirements for developing the West Yellowstone geothermal resource are unknown. Possible surface water resources include Hebge Lake and the Madison River. In terms of groundwater, the site is located on the Continental Divide, and therefore the site is probabiy coincident with major aquifer recharge zones. The suitability of using both local surface water and groundwater requires additional review. 
0 
9.0 WATER RESOURCES FOR DEVELOPMENT OF GEOTHERMAL SITES IN IDAHO

The State of Idaho has numerous geothermal wells and springs. However, most resources are categorized as low enthalpy liquid convection and their suitability for purposes of electrical power generation have yet to be determined. Three sites have been identified by the Department of Energy for possible development. The list of sites includes the Raft River KGRA, the Bruneau-Grandview KGRA, and the Weiser-Crane Creek KGRA.

\section{$9.1 \quad$ RAFT RIVER KGRA}

The Raft River KGRA is located near the Idaho-Nevada-Utah state borders. A 5-MWe binary-cycle demonstration plant is being constructed at the site to determine whether low energy liquid geothermal resources can be commercially developed. The program is being funded by the Department of Energy.

\subsubsection{Geothermal Resource Characteristics}

The Raft River thermal area has been explored extensively by the Department of Energy and its predecessor, the Energy Research and Development Administration. Temperatures of $284^{\circ} \mathrm{F}\left(140^{\circ} \mathrm{C}\right)$ have been measured at a depth of $4,593 \mathrm{ft}(1400 \mathrm{~m})$. Surface area of the resource is estimated to be $7 \times 10^{18} \mathrm{Cal}$. (1) The total dissolved solid content of the reservoir is less than $3000 \mathrm{ppm}$.

Potential development of the Raft River KGRA is set at 800 MWe. The resource is being developed using a binary cycle process. Cooling water requirements are estimated to be 350 to $400 \mathrm{gat}$ per minute based upon the current design of the 5 MWe demonstration plant.

\subsubsection{Water Resources}

The Raft River appears to be the only surface water resource in the vicinity of the KGRA. The Raft River flows north: and joins the Snake River approximately $30 \mathrm{mi}$ north of the site. Groundwater exists, but is not available 
for cooling the 5 MWe demonstration plant. All surface and near surface water of the Raft River Basin has been allocated.

The Raft River is a small tributary of the Snake River. The mean annual flow rate of the $R$ aft $R$ iver near the site is $17.8 \mathrm{ft}^{3} / \mathrm{s}$. Flow rate of the resource is unregulated. Some water is diverted from the resource for purposes of irrigation. The Snake River compact governs the allocation of surface water from the Snake River Basin groundwater resources.

In the vicinity of the Raft River KGRA, groundwaters are contained primarily in the Challis Volcanics. Yields from the formation tend to be small, however, limestone deposits contained in the formation have yielded large quantities of groundwater. (24) All near surface groundwater in the Raft River Basin has been appropriated. Cooling water is derived from processed or treated geothermal water. The cooling water make up requirements, estimated to be 350 to 400 gal per minute, represent approximately $15 \%$ of the geothermal feed.

\subsection{BRUNEAU-GRANDVIEW KGRA}

The Bruneau-Grandview KGRA is located in the southwest corner of Idaho. The site is located approximately $40 \mathrm{mi}$ south of Boise along the Snake River. The Bruneau-Grandview KGRA represents a significant source for electrical power generation provided conversion of low energy liquid geothermal resources proves to be commercially feasible.

\subsubsection{Geothermal Resource Characteristics}

The characteristics of the Bruneau-Grandview KGRA are not well defined. Numerous warm and hot artesian wells and springs exist in the area. The U.S. Geological Survey has estimated the surface area of the resource to be in excess of 500,000 acres. (1) Heat content of the reservoir is estimated to be $450 \times 10^{18} \mathrm{cal}$. An exploratory well drilled to a depth of $11,000 \mathrm{ft}$ measured resource temperatures of $392^{\circ} \mathrm{F}\left(200^{\circ} \mathrm{C}\right)$. The average reservoir 
temperature is $230^{\circ} \mathrm{F}\left(110^{\circ} \mathrm{C}\right) .(1)$ The development scenario proposed by the Department of Energy calls for 150 MWe of capacity to be installed prior to 1990. Site potential is estimated to be 3000 MWe.

Assuming the resource will be developed using a binary cycle, considerable water will be required for a totally wet cooling water system. Water requirement could range as high as 4500 gal per minute/100 MWe.

\subsubsection{Water Resources}

The Bruneau-Grandview KGRA is located in the Central Snake subregion of the Columbia-North Pacific Water Resources Region. The Snake River is the major surface water resource in the subregion. Throughout most of the subregion, the river is entrenched in a deep canyon. The mean average annual flow of the Snake River in the vicinity of the KGRA is $10,000 \mathrm{ft}^{3} / \mathrm{s}$. Large amounts of water are diverted for purposes of irrigation, using high lift pumps. The irrigation extends into Oregon and Nevada. A water rights doctrine of appropriation based upon beneficial usage is used in the region for allocating the water. At the present time no shortages of water exist, but continued expansion of high lift pumping stations are expected to reduce supplies significantly.

Porous and permeable coarse sand and gravel deposits are common in the Snake River Valley. These formations yield moderate to large supplies of groundwater. Total dissolved solid content of the water tends to be greater than $500 \mathrm{ppm}$, thereby making the water moderately hard.

\subsection{WEISER-CRANE CREEK KGRA}

The Weiser-Crane Creek KGRA is located close to the Oregon-Idaho border near Weiser, Idaho. The Weiser River flows through the KGRA. 


\subsubsection{Geothermal Resource Characteristics}

The characteristics of the KGRA are not well defined. The best estimate of subsurface fluid temperature is approimately $284^{\circ} \mathrm{F}\left(140^{\circ} \mathrm{C}\right)$ at $3,281 \mathrm{ft}$ $(1000 \mathrm{~m})$. The resource is classified as : a low enthalpy convective resource. It is assumed that the binary fluid conversion process system will be required to develop the resource. Water resource requirements are estimated to range as high as $6000 \mathrm{gal}$ per minute per $100 \mathrm{MWe}$. The development scenario postulated by the Department of Energy sets the electrical energy potential at 1000 MWe. Scheduled development will begin in the late 1980 's.

\subsubsection{Water Resources}

Both surface water and groundwater are available for developing the geothermal resource. The average annual flow rate of the Weiser River at Weiser, Idaho is $1176 \mathrm{ft}^{3} / \mathrm{s}$. Flow is partially regulated by Crane Creek Reservoir. Upstream diversions for irrigation are small. The Snake River is located within $30 \mathrm{mi}$ of the KGRA. The average annual flow rate of the Snake River at Weiser is approximately $18,000 \mathrm{ft}^{3} / \mathrm{s}$.

The groundwater characteristics at the Weiser-Crane Creek KGRA are similar to the groundwater characteristics at the Bruneau-Grandview KGRA. Porous and permeable coarse sand and gravel deposits are common to both the Snake and Weiser River basins. Moderate to moderately large supplies of groundwater can be pumped from the formations. 
Similar to conditions in Idaho, Oregon hosts a number of low enthalpy liquid convective geothermal resource sites. To a large extent, their suitability for purposes of electrical power generation has not been determined. Two sites, the Vale Hot Springs KGRA, and the Alvord KGRA, will be discussed in the following paragraphs. A third site, the Mount Hood KGRA, has been mentioned in some geothermal development scenarios, but a lack of resource data precludes its inclusion.

\subsection{VALE HOT SPRINGS KGRA}

The Vale Hot Springs KGRA is located 10 miles west of Ontario, Oregon. The resource is located in the Malheur Valley.

\subsubsection{Geothermal Resource Characteristics}

Exploration of the Vale Hot Springs KGRA has been extremely limited. Definition of the resource characteristics and development potential are largely speculative. Reservoir reconnaissance work has been initiated by the U.S. Geological Survey. Subsurface temperatures of the resource are estimated to range from $320^{\circ} \mathrm{F}$ to $356^{\circ} \mathrm{F}\left(160^{\circ} \mathrm{C}\right.$ to $\left.180^{\circ} \mathrm{C}\right) .{ }^{(1)}$ Depth to the top of the reservoir is estimated to be $3,281 \mathrm{ft}(1000 \mathrm{~m})$. Total surface area of the KGRA is estimated to be approximately 23,000 acres. The development potential proposed by the Department of Energy is estimated to be 800 MWe.

\subsubsection{Water Resources}

The Malheur Valley receives 8 in. of precipitation annually. The Malheur River is the principal surface water resource in the basin. The Malheur River flows east, entering the Snake River near Ontario, Oregon. The mean annual average discharge of the Malheur River is $202 \mathrm{ft}^{3} / \mathrm{s}$. Total drainage area of Malheur River basin is $3000 \mathrm{sq}$ "mi. Flow of the Malheur River is regulated by several reservoirs. Diversions for purposes of irrigation are 
extensive. The Malheur River has a high phosphate content, largely the result of irrigation return.

Alluvial deposits occur in the Malheur River Valley. Porous and permeable course sand and gravel deposits are thick and yield large quantities of groundwater. Yields from 50 to $150 \mathrm{ft}$ of the course material are commonly found to be 500 to $2500 \mathrm{gpm}$. The extent of development of the groundwater resource in the Malheur River basin is unknown.

\subsection{ALVORD KGRA}

The Aivord KGRA is located in the southeastern corner of Oregon. The resource is located in the Malheur Valley. The Malheur Valley is a closed drainage basin in southeastern Oregon.

\subsubsection{Geothermal Resource Characteristics}

The characteristics of the Alvord KGRA have not been well defined. Shallow exploratory wells have been drilled, but no deep wells have been drilled. The subsurface temperature of the resource is estimated to be $329^{\circ} \mathrm{F}$ $\left(165^{\circ} \mathrm{C}.\right)$ Several surface springs exist in the area. The Department of Energy development scenario postulates a potential installed capacity of 300 MWe from the Alvord KGRA. Development of the site is postulated to occur in the late 1980 's.

\subsubsection{Water Resources}

Surface water sources in the Malheur drainage basin are scarce. In the vicinity of the Alvord KGRA, potential surface water sources are limited to Alvord Lake and Trout Creek. Valley regions of the Malheur drainage basin are characterized with alluvial deposits that yield groundwater.

Trout Creek is a relatively small surface water resource that flows out of Alvord Lake. Average annual flow rate of the resource is less than $15 \mathrm{ft}^{3} / \mathrm{s}$. 
Flow rate of Trout Creek has been intermittent during the period that records have been collected. Flow rate of Trout Creek is essentially unregulated and diversion for irrigation is significant.

The reliability of Alvord Lake as a source of cooling water is unknown. The U.S. Geological Survey does not monitor the resource.

Groundwater Resource -- Alvord Lake and Trout Creek serve as sources of recharge for the Malheur basin. In the Trout Creek drainage basin, there appears to be good groundwater resources. Yields from good, coarse grained aquifers commonly range from a few hundred to more than $1000 \mathrm{gpm}$. The annual total yield from groundwater pumpage in the Oregon Closed Basin Subregion Valley is estimated to be 70,000 acre- $f t,(24)$ which represents less than 10 percent of the natural recharge. 
Washington hosts several geothermal resource areas that are small in surface area and total heat content. The exception would be the Mount Baker Hot Springs. The Mount Baker KGRA is located in Mount Baker National Park, an environmentally sensitive and primitive recreational area. The projected cost of electricity from a plant at this site is high, and the existence of a reservoir that will support commercial development remains to be proven.

The Mount Baker KGRA lies in the northeast corner of Washington, in the Cascade Mountains some thirty miles east of Bellingham. The characteristics of this resource have not been well defined. The subsurface temperature is estimated at approximately $275^{\circ} \mathrm{F}\left(135^{\circ} \mathrm{C}\right) .(1)$ Surface and groundwater resources are plentiful near the KGRA. In fact, several surface springs exist in the area. The mean annual precipitation in the north Cascades is over 100 inches. Major surface water resources include Baker Lake and Lake Shannon.

Since this resource is located within the confines of a national park, future development of the KGRA will require coordination with the United States Forest Service. 


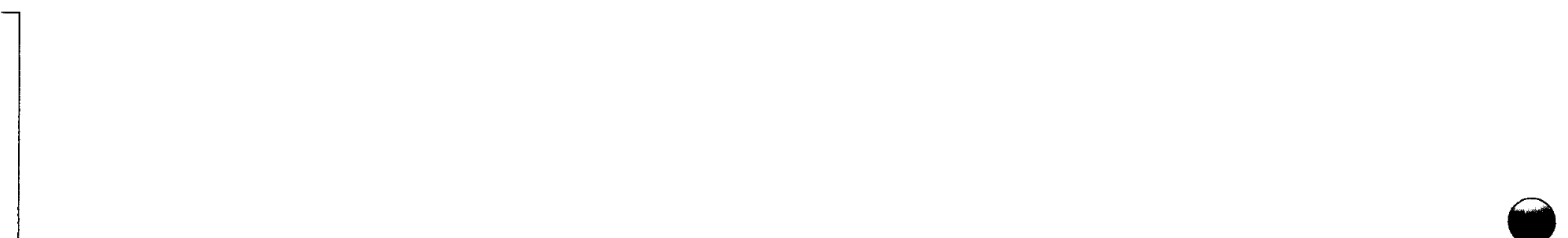

$\bullet$
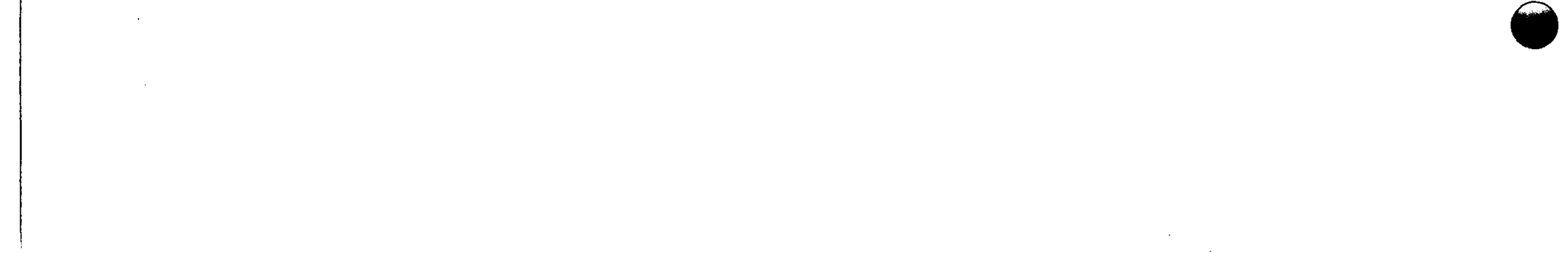


\subsection{REFERENCES}

1. United States Department of the Interior, "Assessment of Geothermal Resources of the United States," Geological Survey Circular 790, 1978.

2 R. C. Robertson, Waste Heat Rejection from Geothermal Power Stations, Oak Ridge NationaT Laboratory/TM-6533, December 1978.

3. R. DiPippi, "Status of World Geothermal Power Development", Department of Mechanical Engineering, Brown University, January 1980.

4. US Department of Energy, Geothermal Energy, Research, Development and Demonstration Program, DOE/ET-0090, March 1979.

5. L. M. Price, "Using Geothermal Energy for Power", Power, Vol. 123, No. 10, October 1979.

6. US Department of Interior, "Water Resources Data for California Water Year 1975, Vol. 2", US Geological Survey Water Data Report CA-75-2.

7. "Water for California: The California Water Plan Outlook in 1970," Department of Water Resources Bulletin No. 160-70, State of California, 1970.

8. "Comprehensive Framework Study California Region," Appendix V, Water Resources, Water Resources Council, 1971.

9. Water Resources Counci1, "The Second National Water Assessment," December 1978.

10. J. E. Dobson, Water Availability Problems for Energy Development to 1990, Oak Ridge National Laboratory/TM-6777, 1979.

11. US Department of Energy, Regional Systems Development for Geothermal Energy Resources, Pacific Region, D0E/ET/28432-3/1, March 1979.

12. US Department of Interior, "Water Resources Data for California Water Year 1975," Volume 4, US Geological Survey Water Data Report CA-75-4, 1975.

13. A. D. Shepherd, Energy-Competition-for-Water in Potential Water Availability Problem Basins. Oak Ridge National Laboratory, November 1979.

14. R. W. Rex, "Investigation of Geothermal Resources in the Imperial Valley and Their Potential Value for Desalination of Water and Electricity Production," University of California, Riverside, 1970. 


\subsection{REFERENCES (Cont'd)}

15. D. A. Tuogood, "Agriculture and the Colorado River", presented Conference on Western Water Issues, Cal ifornia Institute of Technology, May 1979.

16. E. L. Griffith, "Overview of Future Water Supply Availability to Metropolitan Water District of Southern California", presented Conference on Western Water Issues, California Institute of Technology, May 1979.

17. "Lower Colorado Region Comprehensive Framework Study", Appendix V, Water Resources, Waster Resources Council, June 1971.

18. W. C. Lewis, "Water Demand and Supply Inventory: The Utah Great Basin Region", Department of Economics Utah State University, May 1979.

19. US Department of Interior, "Water Resources Data for Utah Water Year 1975", US Geological Survey Water Data Report UT-75-1.

20. "Great Basin Region Comprehensive Framework Study", Appendix V, Water Resources, Water Resources Counci1, June 1971.

21. US Department of Energy, Final Environmental Impact Statement Geothermal Demonstration Program, 50 MW Power Plant Baca Ranch Sandoval and Rio Arriva Counties, New Mexico, D0E/ETS-0049, April 1979.

22. An Investigation of the Potential for Utilization of Saline Groundwater in Energy-Related Processes, Energy Research and Development Administration, FE-2444-1, May 1977.

23. Louis Iwler, Electrical World, McGraw \& Hi11, N.Y., N.Y., October 15, 1979.

24. "Columbia-North Pacific Region Comprehensive Framework Study", Appendix V, Vol. 1 \& 2, Water Resources, September 1972.

25. US Department of Interor, Water Resources Data for Nevada Water Year 1975, US Geological Survey Water Data Report NV-76-1, 1975. 


\section{DISTRIBUTION}

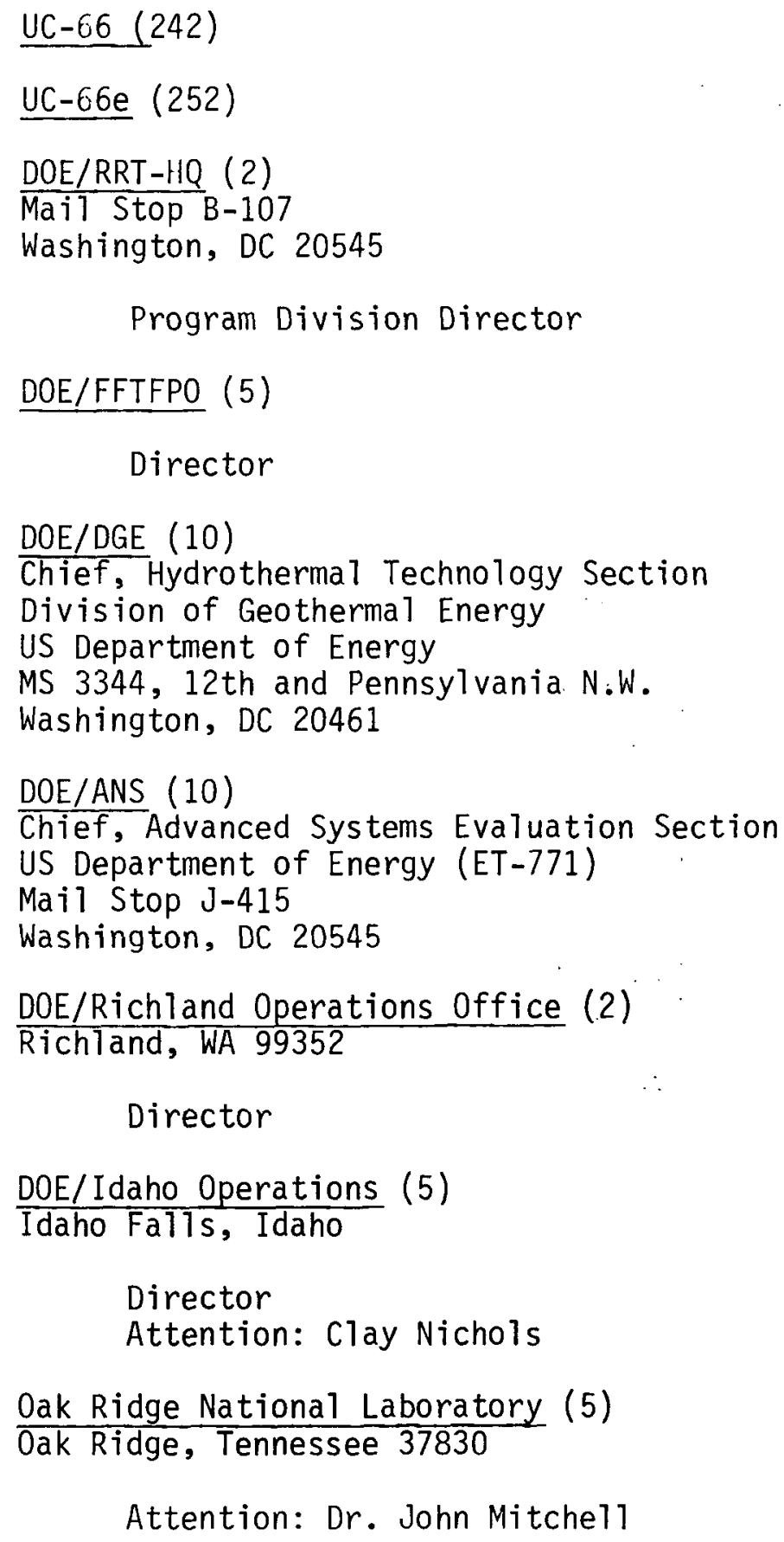




\section{DISTRIBUTION (Cont'd)}

DOE/San Francisco Operations

San Francisco, CA

Attention: Tom Heenan

U.S. Geological Survey (5)

12201 Sunrise Valley Drive

Reston, Virginia 22092

Attention: Don K1ick

HEDL (20)

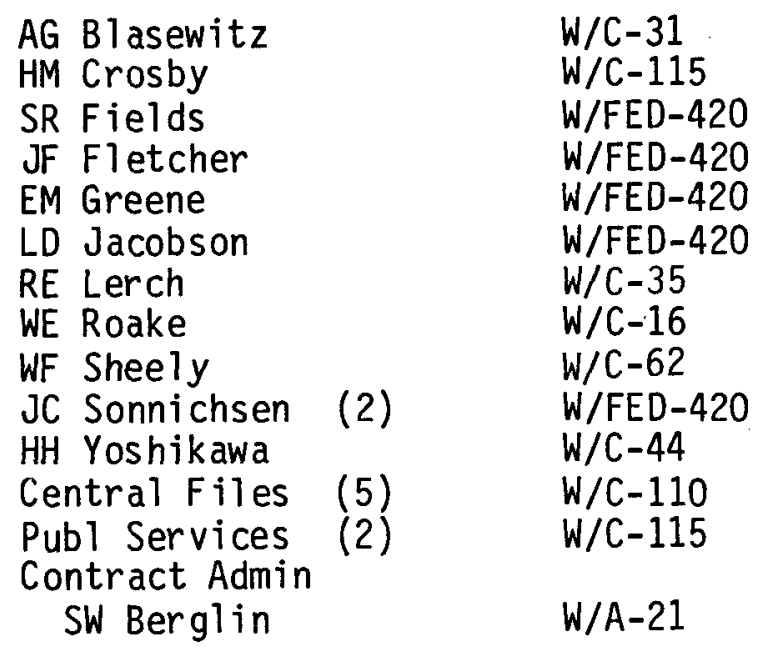

